Nevada

Environmental

Restoration

Project

\title{
Closure Report for Corrective Action Unit 145: Wells and Storage Holes, Nevada Test Site, Nevada
}

Controlled Copy No.:

Revision: 0

February 2008

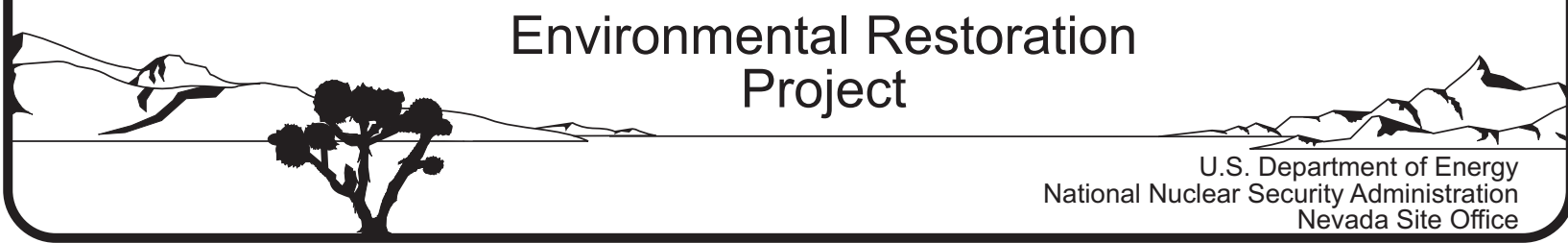




\section{DISCLAIMER}

Reference herein to any specific commercial product, process, or service by trade name, trademark, manufacturer, or otherwise, does not necessarily constitute or imply its endorsement, recommendation, or favoring by the United States Government or any agency thereof or its contractors or subcontractors.

This report has been reproduced directly from the best available copy.

Available for sale to the public from:

U.S. Department of Commerce

National Technical Information Service

5285 Port Royal Road

Springfield, VA 22161-0002

Telephone: (800) 553-6847

Fax: (703) 605-6900

E-mail: orders@ntis.gov

Online ordering: http://www.ntis.gov/ordering.htm

Available electronically at http://www.osti.gov/bridge.

Available for a processing fee to the U.S. Department of Energy and its contractors, in paper, from:

U.S. Department of Energy

Office of Scientific and Technical Information

P.O. Box 62

Oak Ridge, TN 37831-0062

Telephone: (865) 576-8401

Fax: (865) 576-5728

E-mail: reports@adonis.osti.gov 


\title{
CLOSURE REPORT FOR CORRECTIVE ACTION UNIT 145: WELLS AND STORAGE HOLES, NEVADA TEST SITE, NEVADA
}

\author{
U.S. Department of Energy \\ National Nuclear Security Administration \\ Nevada Site Office \\ Las Vegas, Nevada
}

Controlled Copy No.

Revision: 0

February 2008 
THIS PAGE INTENTIONALLY LEFT BLANK 


\section{CLOSURE REPORT FOR CORRECTIVE ACTION UNIT 145: WELLS AND STORAGE HOLES, NEVADA TEST SITE, NEVADA}

\footnotetext{
Federal Sub-Project Director Industrial Sites Sub-Project
}

Approved By: Original signed by: J Jones John B. Kones Acting Federal Project Director Environmental Restoration Project
Date: $2 / 6 / 08$

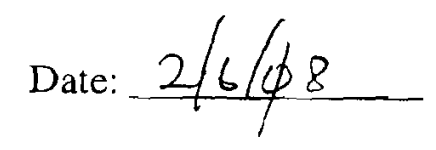


THIS PAGE INTENTIONALLY LEFT BLANK 
ACRONYMS AND ABBREVIATIONS ......................................................................... vii

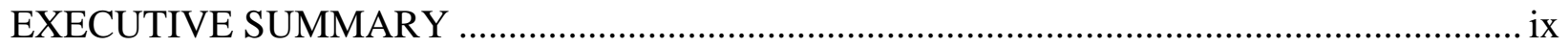

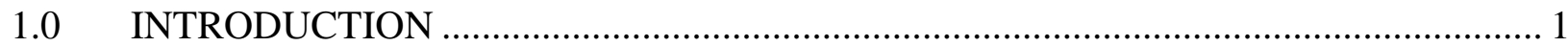

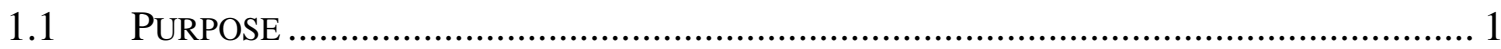

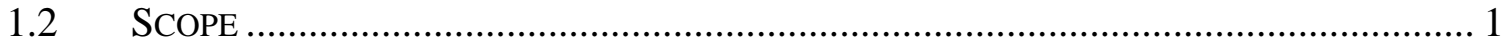

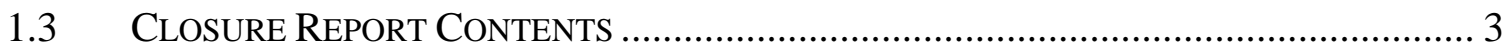

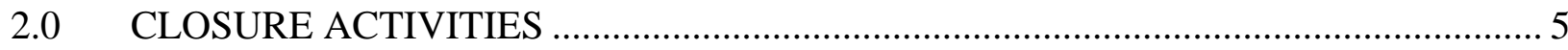

2.1 DESCRIPTION OF CORRECTIVE ACTION ACTIVITIES ............................................... 5

2.1.1 Preplanning and Site Preparation ............................................................. 5

2.1.2 Closure Activities............................................................................ 5

2.1.2.1 CAS 03-20-01, Core Storage Holes ................................................... 5

2.1.2.2 CAS 03-20-02, Decon Pad and Sump ................................................ 5

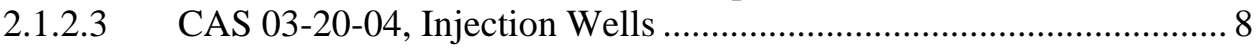

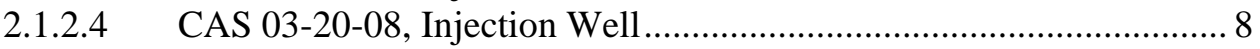

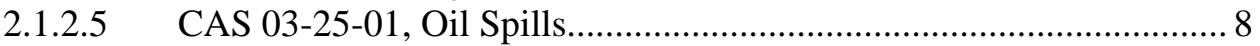

2.1.2.6 CAS 03-99-13, Drain and Injection Well ........................................ 13

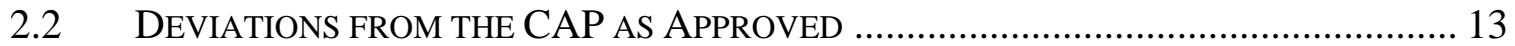

2.3 CORRECTIVE ACTION SCHEDULE AS COMPLETED ................................................ 13

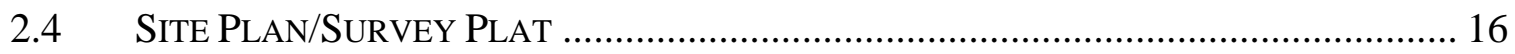

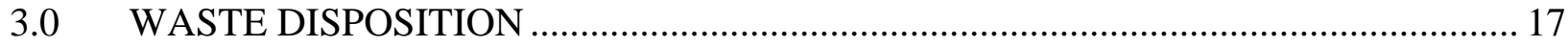

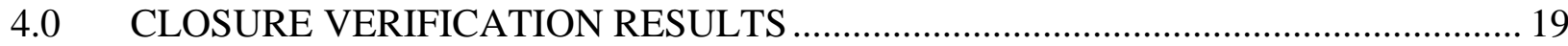

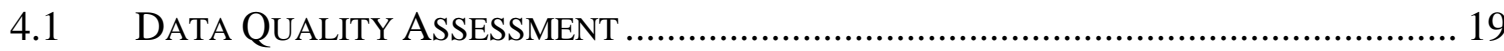

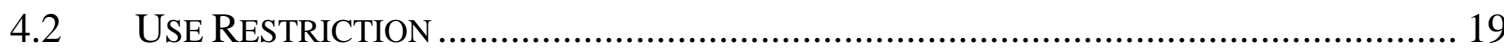

4.2.1 CAS 03-20-02, Decon Pad and Sump..................................................... 19

4.2.2 CAS 03-20-04, Injection Wells............................................................. 19

4.2.3 CAS 03-20-08, Injection Well ............................................................. 19

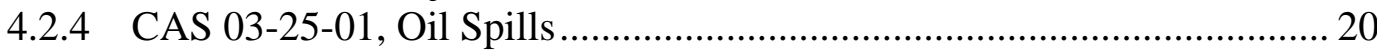

5.0 CONCLUSIONS AND RECOMMENDATIONS ................................................ 21

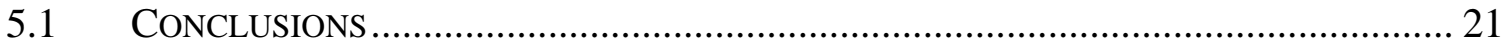

5.2 POST-CLOSURE REQUIREMENTS .................................................................... 21

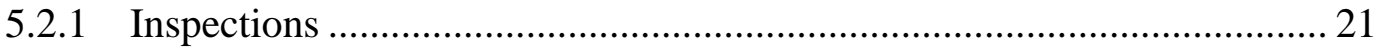

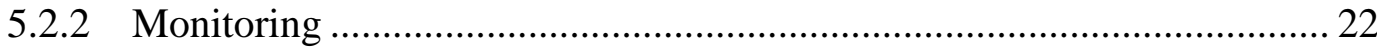

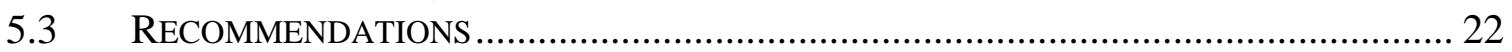

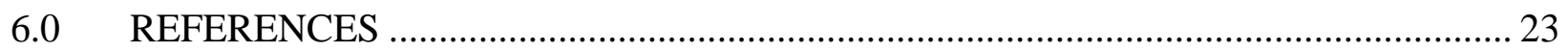

LIBRARY DISTRIBUTION LIST 


\section{LIST OF FIGURES}

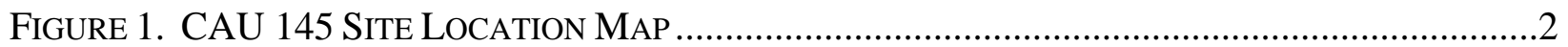

FIGURE 2. CAS 03-20-01, Core STORAGE HolES ..............................................................

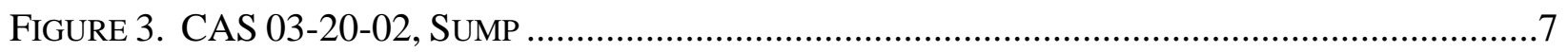

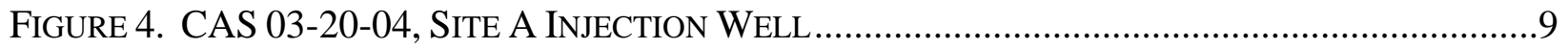

FIGURE 5. CAS 03-20-04, SitE B INJECTION WELL ..........................................................

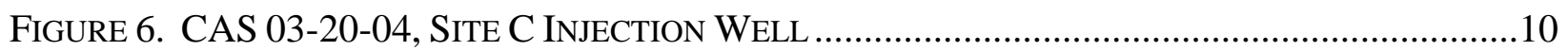

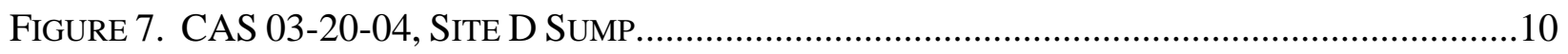

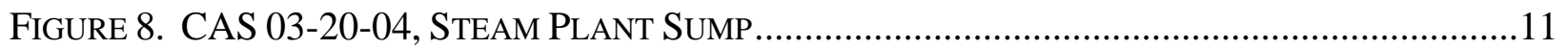

Figure 9. CAS 03-20-04, SiTE E STEEL-CASED HOLE ..............................................................11

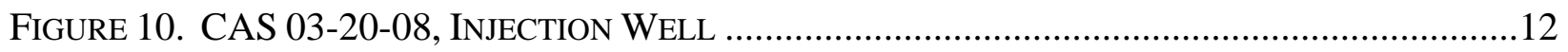

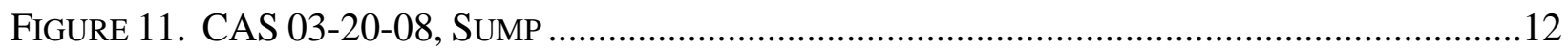

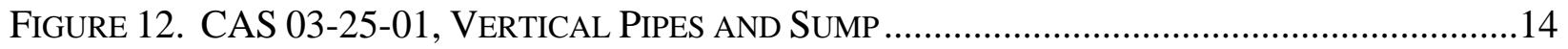

FIGURE 13. CAS 03-25-01, USE RESTRICTION SIGN ..........................................................14

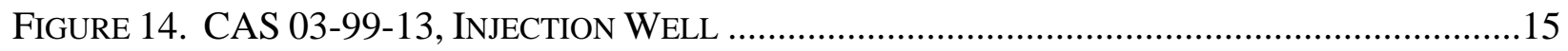

\section{LIST OF TABLES}

TABLE 1. SUMmARY OF CAU 145 ClOSURE ACTIVITIES ...........................................................6

TABle 2. CAU 145 Closure Activities SChedule .................................................................15

\section{APPENDICES}

ApPendix A. Use Restriction DOCUMENTATION 


\section{ACRONYMS AND ABBREVIATIONS}

BMP best management practice

CADD Corrective Action Decision Document

CAP Corrective Action Plan

CAS Corrective Action Site

CAU Corrective Action Unit

COC contaminant of concern

CR Closure Report

FFACO Federal Facility Agreement and Consent Order

NDEP Nevada Division of Environmental Protection

NNSA/NSO U.S. Department of Energy, National Nuclear Security Administration Nevada Site Office

NTS Nevada Test Site

UR use restriction 
Closure Report - CAU 145

Section: Acronyms and Abbr.

Revision: 0

Date: February 2008

THIS PAGE INTENTIONALLY LEFT BLANK 


\section{EXECUTIVE SUMMARY}

Corrective Action Unit (CAU) 145 is identified in the Federal Facility Agreement and Consent Order (FFACO, 1996) as Wells and Storage Holes. CAU 145 is located in Area 3 of the Nevada Test Site (NTS), Nevada, and consists of the following six Corrective Action Sites (CASs):

- CAS 03-20-01, Core Storage Holes

- CAS 03-20-02, Decon Pad and Sump

- CAS 03-20-04, Injection Wells

- CAS 03-20-08, Injection Well

- CAS 03-25-01, Oil Spills

- CAS 03-99-13, Drain and Injection Well

CAU 145 closure activities started in August 2007 and were completed in September 2007. Activities were performed in accordance with the FFACO and the Corrective Action Plan for CAU 145 (U.S. Department of Energy, National Nuclear Security Administration Nevada Site Office, 2006b). The corrective action alternatives that were applied at each site consisted of closure in place with administrative controls and no further action with best management practices (BMPs).

CAS 03-25-01, located at the former Area 3 Subdock Complex, was closed in place with administrative controls. Two vertical pipes and the sump surrounding them were filled with grout to grade. A use restriction (UR) was implemented around an area that has surface lead contamination and subsurface pentachlorophenol and arsenic contamination.

The remaining CASs were closed by taking no further action with implementation of the following BMPs:

- CAS 03-20-01: Core storage holes were filled with grout to grade.

- CAS 03-20-02: A sump was filled with grout to grade, and an administrative UR was established to warn against working at this location for more than 50 cumulative workdays because of exposure hazards.

- CAS 03-20-04: Liquid was removed from an injection well (Site C) and a steel-cased hole (Site E) to the extent practical. Three injection wells (Sites A, B, and C), two sumps (Site D and the steam plant sump), and one steel-cased hole (Site E) were then filled with grout to grade. An administrative UR was established to warn against working at this location for more than 50 cumulative workdays because of exposure hazards.

- CAS 03-20-08: An injection well and a sump were filled with grout to grade. An administrative UR was established to warn against working at this location for more than 50 cumulative workdays because of exposure hazards.

- CAS 03-99-13: The injection well was filled with grout to grade. 
Liquid removed from the wells, sumps, and holes was disposed of appropriately. Covers from the wells, sumps, and holes were placed back into metal stockpiles for use elsewhere on the NTS. No samples were required to complete these closure activities. Closure activities generated approximately 700 gallons of liquid waste that was disposed of in the Area 12 Sewage Lagoon. This closure report documents the activities taken to close this CAU. 
This Closure Report (CR) documents closure activities for Corrective Action Unit (CAU) 145, Wells and Storage Holes, according to the Federal Facility Agreement and Consent Order (FFACO, 1996) and the Corrective Action Plan (CAP) for CAU 145 (U.S. Department of Energy, National Nuclear Security Administration Nevada Site Office [NNSA/NSO], 2006b). CAU 145 is located at the Nevada Test Site (NTS), Nevada (Figure 1), and consists of the following six Corrective Action Sites (CASs):

- CAS 03-20-01, Core Storage Holes

- CAS 03-20-02, Decon Pad and Sump

- CAS 03-20-04, Injection Wells

- CAS 03-20-08, Injection Well

- CAS 03-25-01, Oil Spills

- CAS 03-99-13, Drain and Injection Well

All CASs are located in Area 3 of the NTS.

\subsection{Purpose}

The purpose of this CR is to provide a summary of the completed closure activities, to document waste disposal, and to present information confirming that the remediation goals were met. The closure alternatives consisted of closure in place with administrative controls for one CAS, and no further action with implementation of best management practices (BMPs) for the remaining five CASs.

\subsection{SCOPE}

The closure strategy for CAU 145 was as follows:

- CAS 03-20-01 (Core Storage Holes) was closed by taking no further action with implementation of BMPs. As a BMP, the seven core storage holes were filled with grout to grade.

- CAS 03-20-02 (Decon Pad and Sump) was closed by taking no further action with implementation of BMPs. The following were undertaken as BMPs: (1) the sump was filled with grout to grade, and (2) an administrative use restriction (UR) was established to warn from working at this location for more than 50 cumulative workdays because of exposure hazards (per the Corrective Action Decision Document [CADD] for CAU 145 [NNSA/NSO, 2006a]).

- CAS 03-20-04 (Injection Wells) was closed by taking no further action with implementation of BMPs. The following were undertaken as BMPs: (1) liquid was removed from an injection well (Site C) and a steel-cased hole (Site E) to the extent practical; (2) three injection wells (Sites A, B, and C), two sumps (Site D and the steam plant sump), and one steel-cased hole (Site E) were filled with grout to grade; and (3) an administrative UR was 


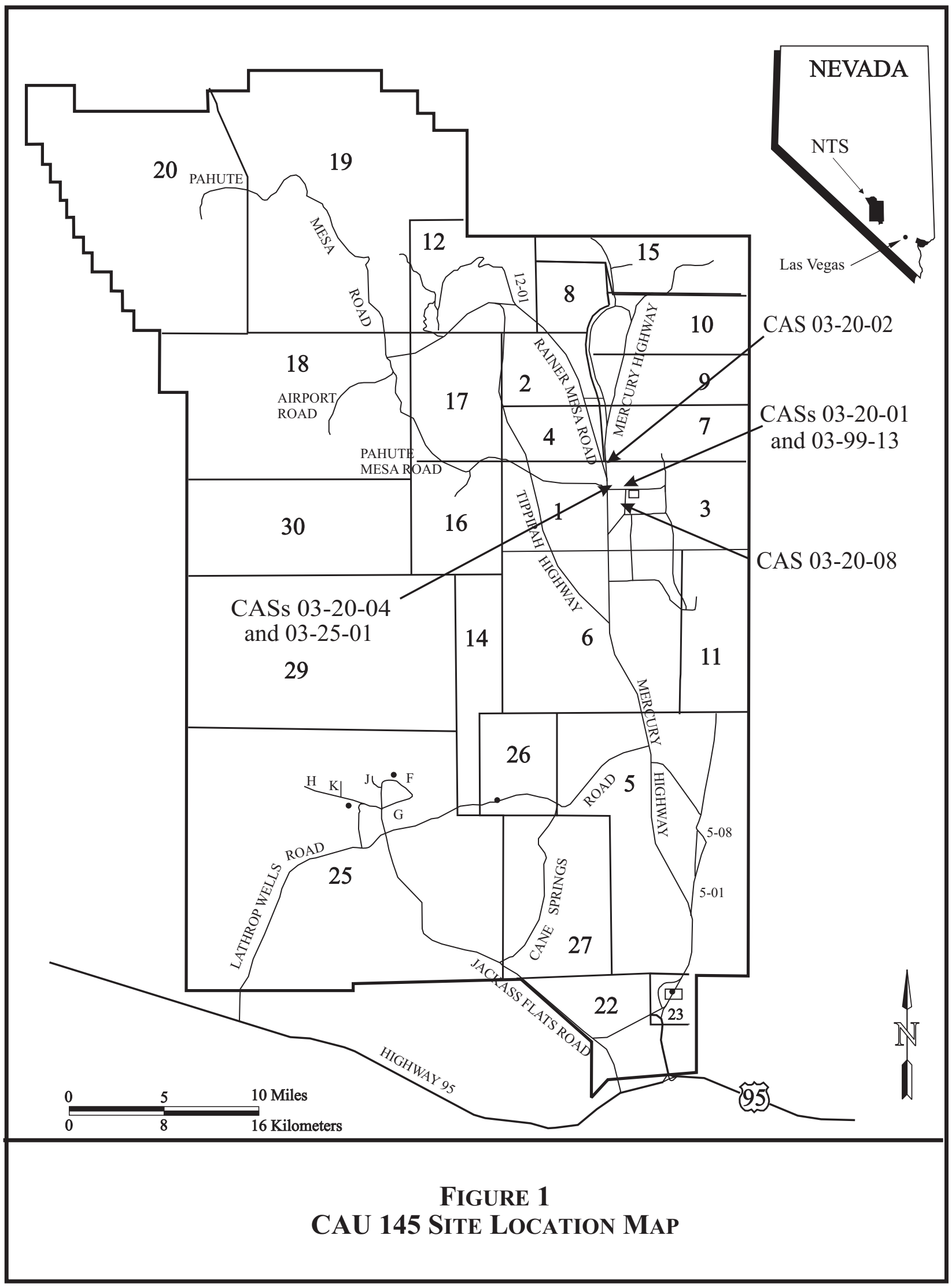


established to warn from working at this location for more than 50 cumulative workdays because of exposure hazards (per the CADD for CAU 145 [NNSA/NSO, 2006a]).

- CAS 03-20-08 (Injection Well) was closed by taking no further action with implementation of BMPs. The following were undertaken as BMPs: (1) the injection well and sump were opened and found to be dry, (2) both the sump and the injection well were filled with grout to grade, and (3) an administrative UR was established to warn from working at this location for more than 50 cumulative workdays because of exposure hazards (per the CADD for CAU 145 [NNSA/NSO, 2006a]).

- CAS 03-25-01 (Oil Spills) was closed in place with administrative controls. The following closure activities were undertaken: (1) the north pipe was opened and the liquid level was found to be minimal; (2) the north and south pipes, and the sump surrounding them, were grouted to grade; (3) UR signs were posted; and (4) a UR was implemented for an area that is contaminated with surface lead and subsurface pentachlorophenol and arsenic.

- CAS 03-99-13 (Drain and Injection Well) was closed by taking no further action with implementation of BMPs. As a BMP, the injection well was filled with grout to grade.

\subsection{Closure Report Contents}

This CR includes the following sections:

- Section 1.0 - Introduction

- $\quad$ Section 2.0 - Closure Activities

- Section 3.0 - Waste Disposition

- Section 4.0 - Closure Verification Results

- Section 5.0 - Conclusions and Recommendations

- Section 6.0 - References

- Appendix A - Use Restriction Documentation

- Library Distribution List

This report was developed using information and guidance from the following documents:

- CAP for CAU 145 (NNSA/NSO, 2006b)

- $\quad$ CADD for CAU 145 (NNSA/NSO, 2006a)

No additional data were collected as part of the closure activities; therefore, there are no data to evaluate or data quality objectives to be met for these closure activities. 
Closure Report - CAU 145

Section: Introduction

Revision: 0

Date: February 2008

THIS PAGE INTENTIONALLY LEFT BLANK 


\subsection{CLOSURE ACTIVITIES}

This section details the specific activities completed during the closure of CAU 145, deviations from the CAU 145 CAP, the schedule of completed activities, and the final site plan. Photographs in this report document the state of the sites before corrective actions were implemented and after completion of work.

\subsection{Description of CoRrective Action Activities}

Closure activities for CAU 145 were completed according to the CAP (NNSA/NSO, 2006b), with minor deviations as documented in Section 2.2. Closure activities consisted of removing and disposing of liquid from wells, sumps, and holes; filling wells, sumps, and holes with grout to grade; and implementing URs. The following sections detail the closure activities as completed. Table 1 identifies the activities that were conducted at each CAS.

\subsubsection{Preplanning and Site Preparation}

Prior to closure activities, the following documents were prepared:

- National Environmental Policy Act Checklist

- Field Management Plan

- NNSA/NSO Real Estate/Operations Permit

- Work control packages

\subsubsection{Closure Activities}

\subsubsection{CAS 03-20-01, Core Storage Holes}

CAS 03-20-01 is located at the former Core Complex in Area 3 of the NTS. It consists of seven cased core storage holes. No further action was required for closure of this CAS. As a BMP, all seven holes were grouted to grade. Metal covers were surveyed to verify that radiological contamination was less than the free-release limit established in the NV/YMP Radiological Control Manual (NNSA/NSO, 2004), after which the covers were placed into metal stockpiles for use elsewhere on the NTS. Photographs of the site before and after closure activities are provided in Figure 2.

\subsubsection{CAS 03-20-02, Decon Pad and Sump}

CAS 03-20-02 is located near the junction of Mercury Highway and the BJY Road. No further action was required for closure of this CAS. As a BMP, the sump was grouted to grade. The metal cover that had covered the sump was surveyed to verify that radiological contamination was less than the free-release limit established in the NV/YMP Radiological Control Manual (NNSA/NSO, 2004), after which it was placed into metal stockpiles for use elsewhere on the NTS. Photographs of the site before and after closure activities are provided in Figure 3. 
Table 1. Summary of CAU 145 Closure Activities

\begin{tabular}{|c|c|c|c|c|}
\hline CAS & CAS Name & $\begin{array}{l}\text { Closure } \\
\text { Method }\end{array}$ & $\mathrm{COC}$ & Closure Activities \\
\hline 03-20-01 & $\begin{array}{c}\text { Core Storage } \\
\text { Holes }\end{array}$ & $\begin{array}{l}\text { No Further } \\
\text { Action with } \\
\text { BMPs }\end{array}$ & None & $\begin{array}{ll} & \text { Filled seven core storage holes with grout. } \\
\text { - } & \text { Recycled/reused covers from the holes. }\end{array}$ \\
\hline 03-20-02 & $\begin{array}{l}\text { Decon Pad and } \\
\text { Sump }\end{array}$ & $\begin{array}{l}\text { No Further } \\
\text { Action } \\
\text { with BMPs }\end{array}$ & None & $\begin{array}{l}\text { - } \quad \text { Filled sump with grout. } \\
\text { - } \quad \text { Recycled/reused cover from the sump. } \\
\text { - Implemented an administrative UR. }\end{array}$ \\
\hline 03-20-04 & Injection Wells & $\begin{array}{l}\text { No Further } \\
\text { Action } \\
\text { with BMPs }\end{array}$ & None & $\begin{array}{ll}\text { - } & \text { Removed liquid from Site C injection well and Site E steel-cased hole. } \\
\text { - } & \text { Disposed of liquid at the Area } 12 \text { Sewage Lagoon. } \\
\text { - } & \text { Filled three injection wells (Sites A, B, and C), two sumps (Site D and the steam plant sump), and one } \\
& \text { steel-cased hole (Site E) with grout. } \\
\text { - } & \text { Recycled/reused covers from wells and sumps. } \\
\text { - } & \text { Implemented an administrative UR. }\end{array}$ \\
\hline 03-20-08 & Injection Well & $\begin{array}{l}\text { No Further } \\
\text { Action } \\
\text { with BMPs }\end{array}$ & None & $\begin{array}{ll}\text { - } & \text { Checked and confirmed that injection well and sump did not contain liquid. } \\
\text { - } & \text { Filled the injection well and sump with grout. } \\
\text { - } & \text { Recycled/reused covers from well and sump. } \\
\text { - } & \text { Implemented an administrative UR. }\end{array}$ \\
\hline 03-25-01 & Oil Spills & $\begin{array}{l}\text { Closure in Place } \\
\text { with } \\
\text { Administrative } \\
\text { Controls }\end{array}$ & $\begin{array}{l}\text { Lead, } \\
\text { Pentachlorophenol, } \\
\text { and Arsenic }\end{array}$ & $\begin{array}{ll}\text { - } & \text { Checked and confirmed that north pipe liquid volume was negligible. } \\
\text { - } & \text { Filled two pipes and the surrounding sump with grout. } \\
\text { - } & \text { Recycled/reused pipe covers. } \\
\text { - } & \text { Posted UR signs to identify use-restricted area. } \\
\text { - } & \text { Implemented a UR for surface lead and subsurface pentachlorophenol and arsenic contamination. }\end{array}$ \\
\hline 03-99-13 & $\begin{array}{c}\text { Drain and } \\
\text { Injection Well }\end{array}$ & $\begin{array}{l}\text { No Further } \\
\text { Action } \\
\text { with BMPs }\end{array}$ & None & $\begin{array}{l}\text { - } \quad \text { Filled well with grout. } \\
\text { - } \quad \text { Recycled/reused cover from well. }\end{array}$ \\
\hline
\end{tabular}

BMP: best management practic

CAS: Corrective Action Site

COC: contaminant of concern

UR: use restriction 


\section{Figure 2. CAS 03-20-01, CorE StORAGE Holes}

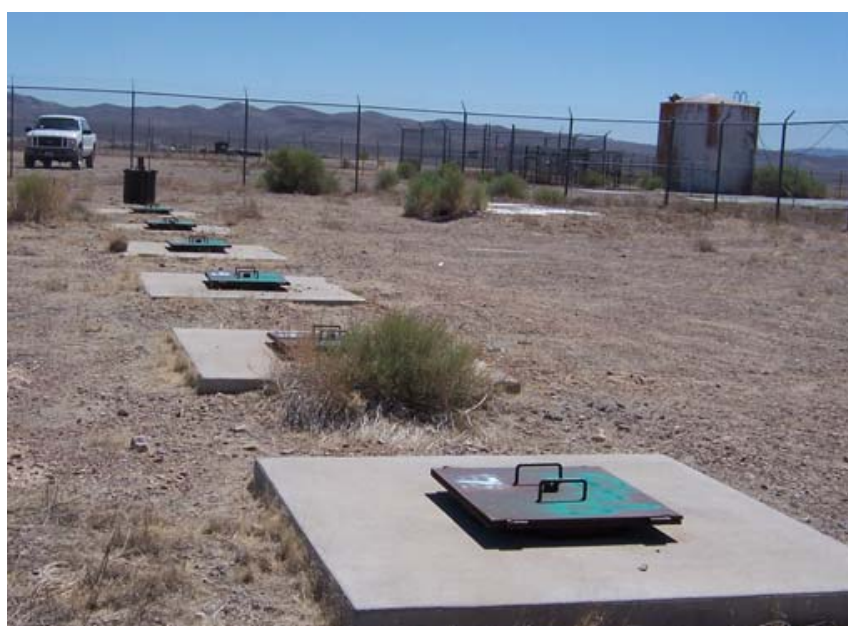

Before (08/09/2007)

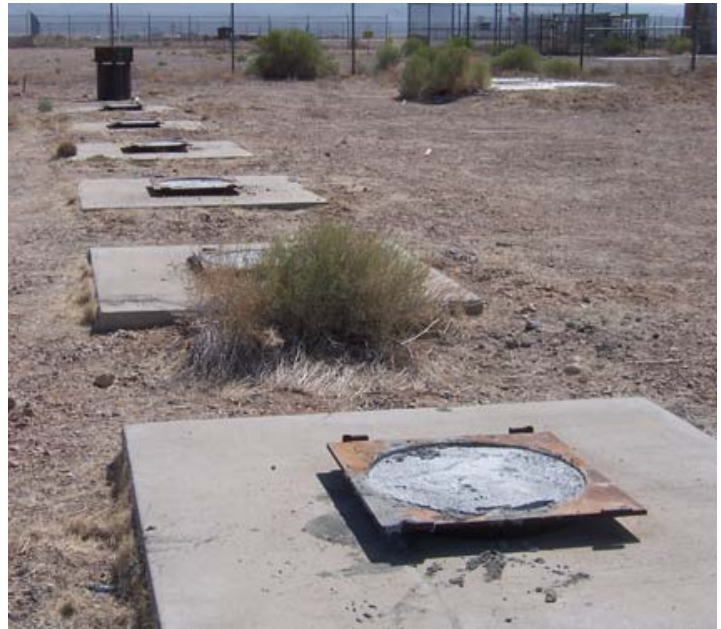

After (09/06/2007)

FIGURE 3. CAS 03-20-02, SUMP

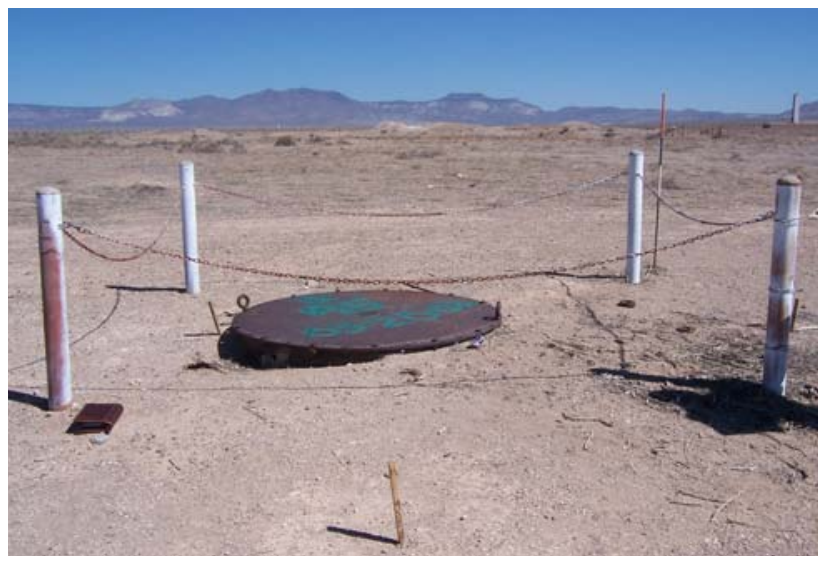

Before (08/09/2007)

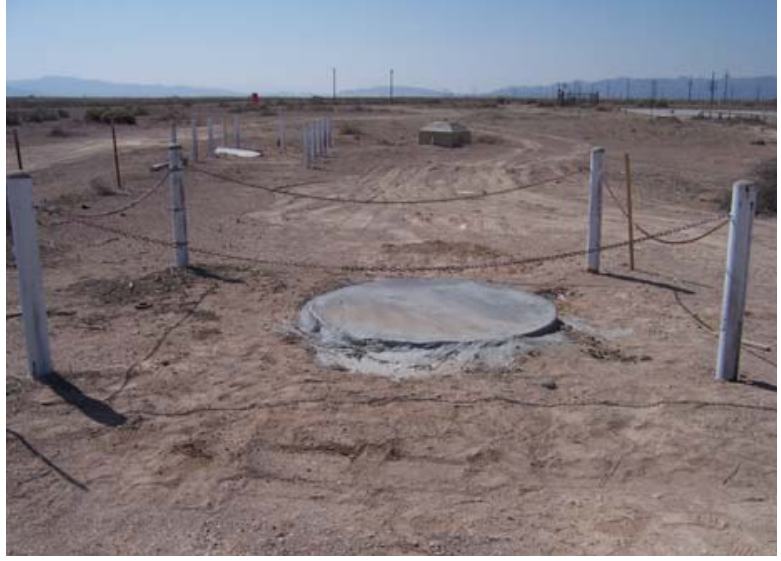

After (09/06/2007) 


\subsubsection{CAS 03-20-04, Injection Wells}

CAS 03-20-04 is located at the former Area 3 Subdock Complex. No further action was required for closure of this CAS. The following activities were undertaken as BMPs:

- Approximately 600 gallons of liquid were pumped from the Site C injection well and disposed of at the Area 12 Sewage Lagoon.

- Approximately 100 gallons of liquid were pumped from the Site E steel-cased hole and disposed of at the Area 12 Sewage Lagoon.

- Three injection wells (Sites A, B, and C), two sumps (Site D and steam plant sump), and one steel-cased hole (Site E) were filled to grade with grout. No liquid was removed from the steam plant sump because it was dry during closure activities.

- Metal covers from the wells and sumps were surveyed to verify that radiological contamination was less than the free-release limit established in the $N V / Y M P$ Radiological Control Manual (NNSA/NSO, 2004), after which the covers were placed back into metal stockpiles for use elsewhere on the NTS.

Photographs of each location before and after closure activities are provided in Figures 4 through 9.

\subsubsection{CAS 03-20-08, Injection Well}

CAS 03-20-08 is located in the J-6 yard in Area 3 of the NTS, just southwest of the Los Alamos Scientific Laboratory Post-Shot Building. No further action was required for closure of this CAS. As a BMP, the injection well and sump were filled with grout to grade. Metal covers from the well and sump were surveyed to verify that radiological contamination was less than the freerelease limit established in the NV/YMP Radiological Control Manual (NNSA/NSO, 2004), after which the covers were placed back into metal stockpiles for use elsewhere on the NTS. No liquid was removed from either the well or the sump because both were dry during closure activities. Photographs of each location, before and after closure activities, are provided in Figures 10 and 11.

\subsubsection{CAS 03-25-01, Oil Spills}

CAS 03-25-01 is located at the former Area 3 Subdock Complex. Surface soil is contaminated with lead, and subsurface soil is contaminated with pentachlorophenol and arsenic at levels requiring restricted use of the area for personnel protection. The site also has two vertical pipes surrounded by a sump. Approximately 100 gallons of liquid were expected within the north pipe based on observations during the corrective action investigation; however, very little liquid was present during closure activities. The volume of liquid was insufficient to pump without also pumping sludge. This site was closed in place with administrative controls.

Both of the vertical pipes were filled with grout to grade. A drier mix was used initially in the north pipe to solidify any liquid and sludge at the liquid-sludge interface. Additional grout was poured to fill the sump around the pipes. The cover was not removed from the sump because it 
Figure 4. CAS 03-20-04, Site A INJECTION WELL

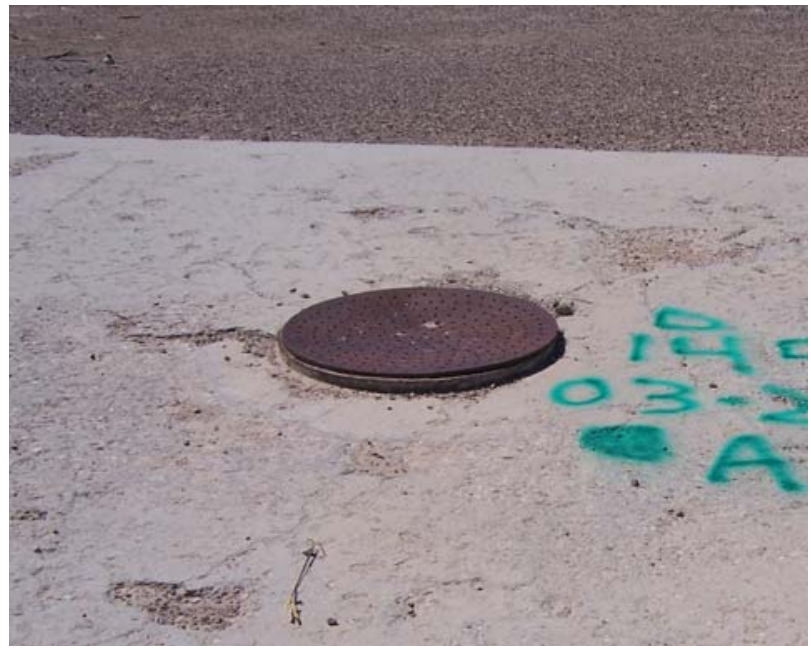

Before (08/09/2007)

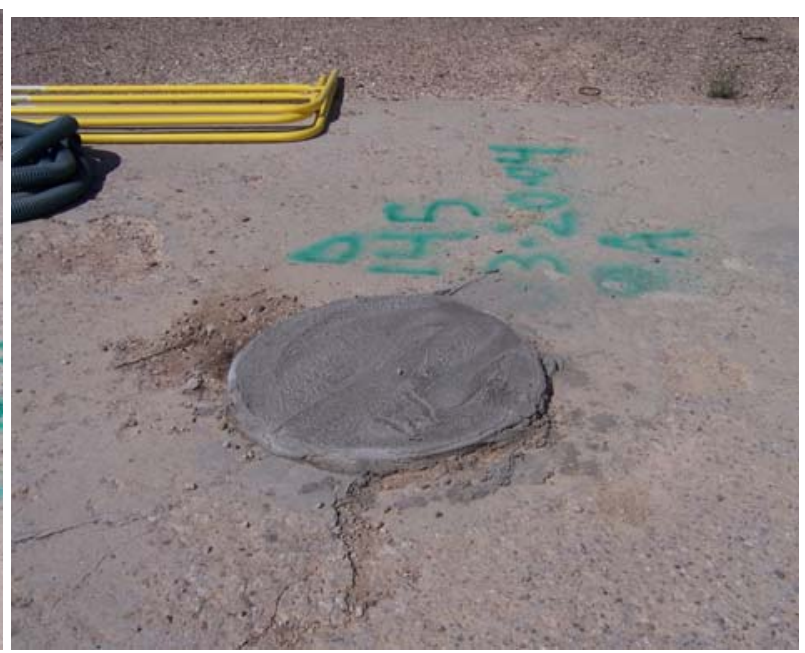

After (09/06/2007)

FiguRE 5. CAS 03-20-04, SITE B INJECTION WELL

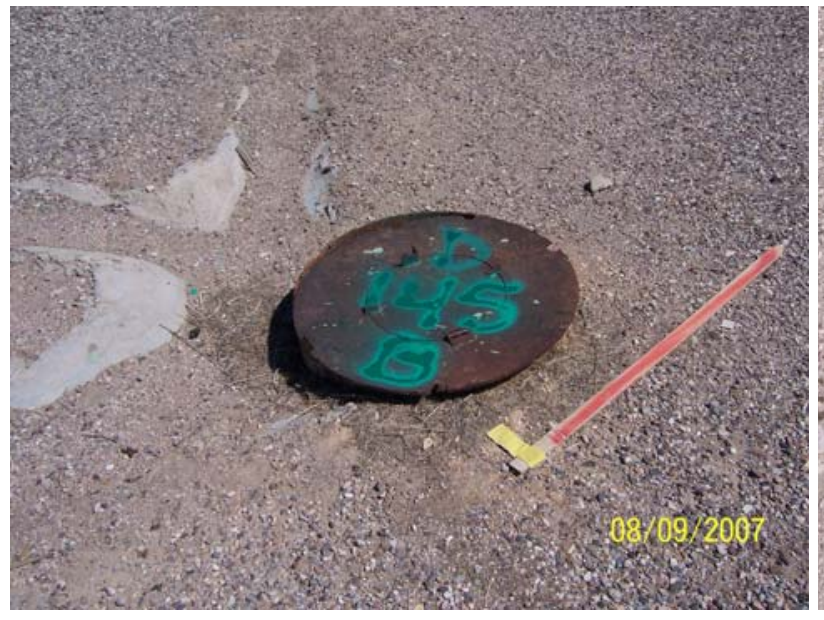

Before (08/09/2007)

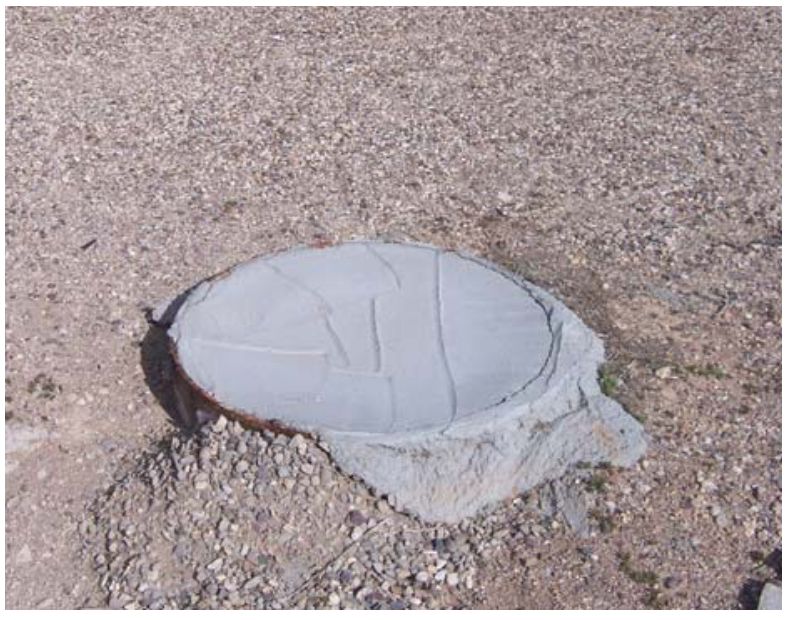

After (10/15/2007) 
FiguRE 6. CAS 03-20-04, SITE C INJECTION WELL

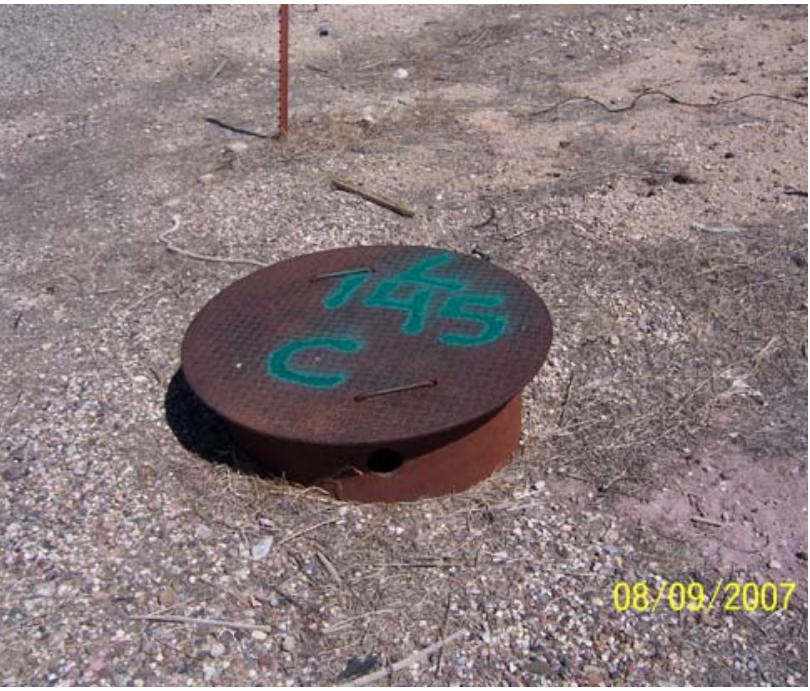

Before (08/09/2007)

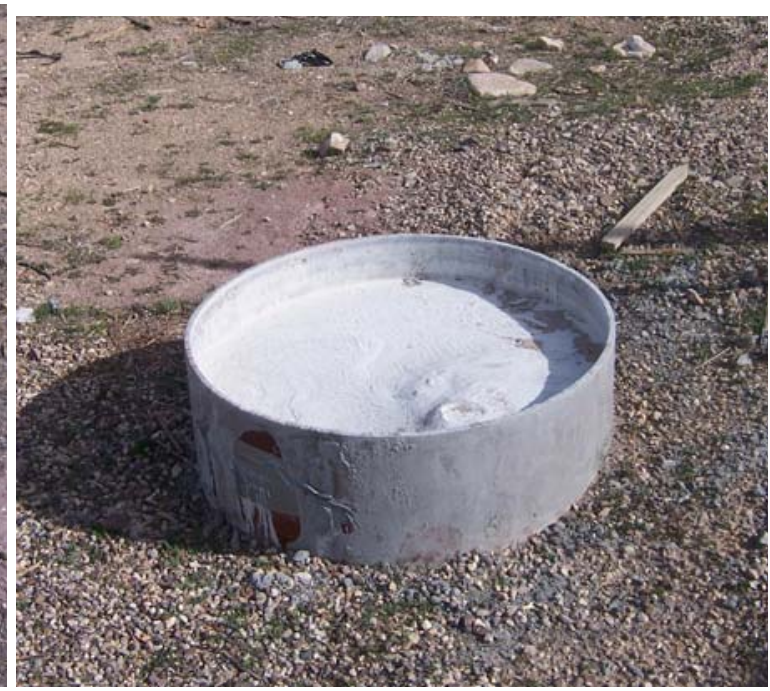

After (10/15/2007)

FigURE 7. CAS 03-20-04, SITE D SUMP

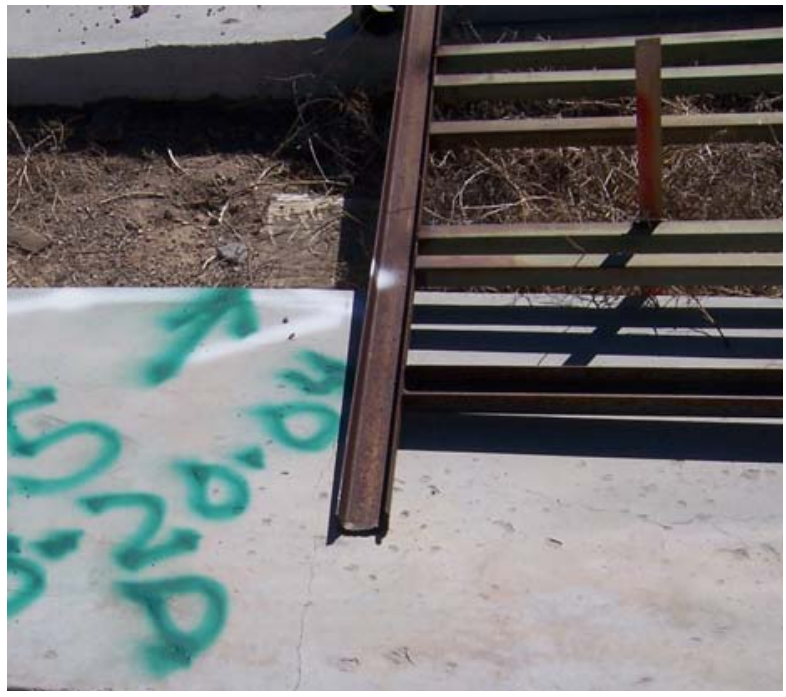

Before (08/09/2007)

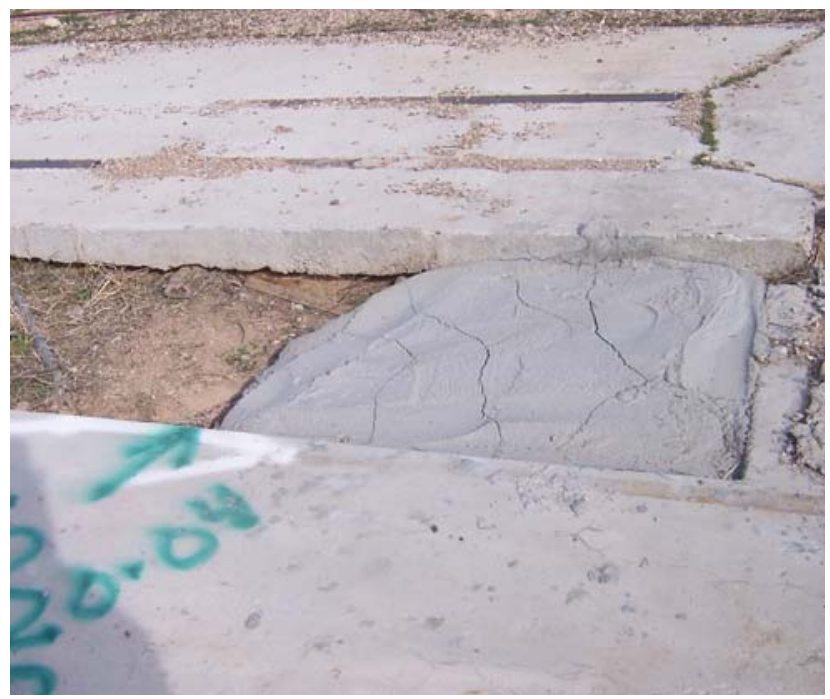

After (10/15/2007) 
Figure 8. CAS 03-20-04, SteAm Plant SuMP

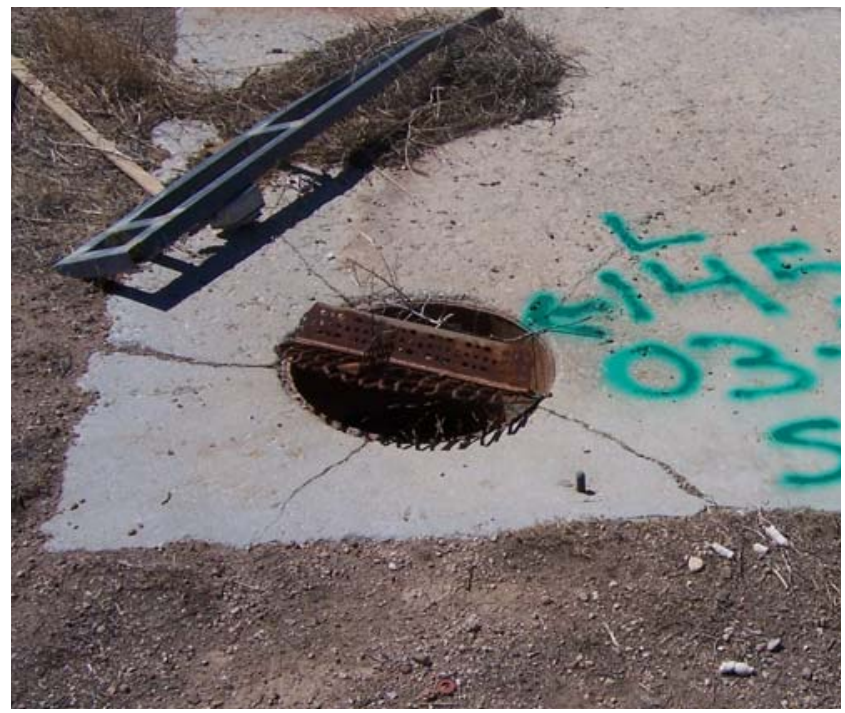

Before (08/09/2007)

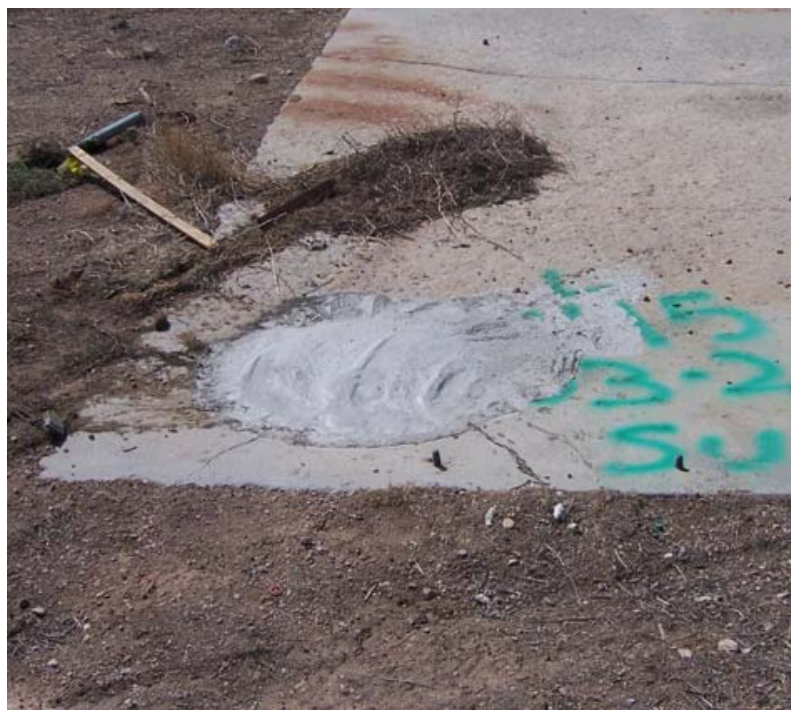

After (09/06/2007)

Figure 9. CAS 03-20-04, Site E STEEL-CASED HoLE

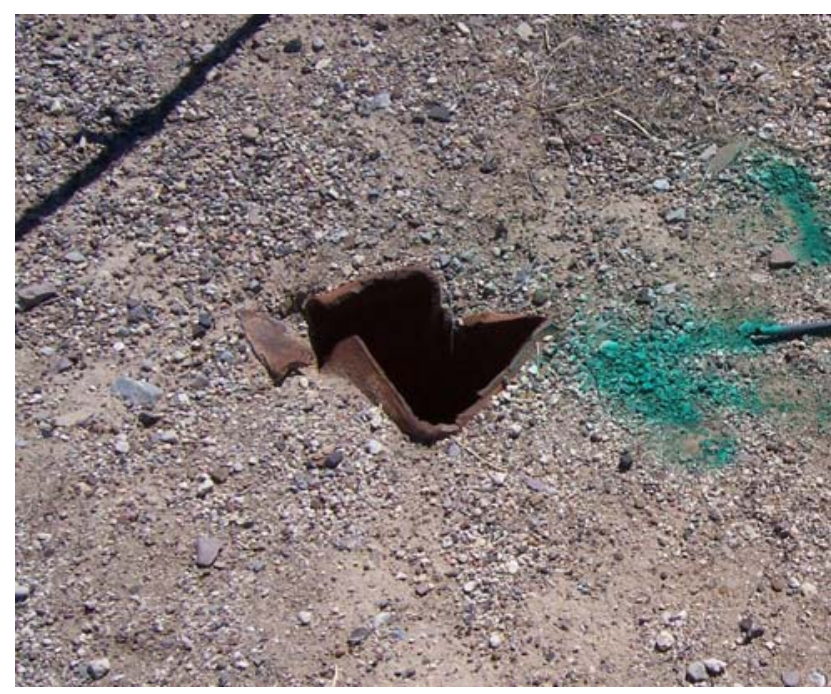

Before (08/09/2007)

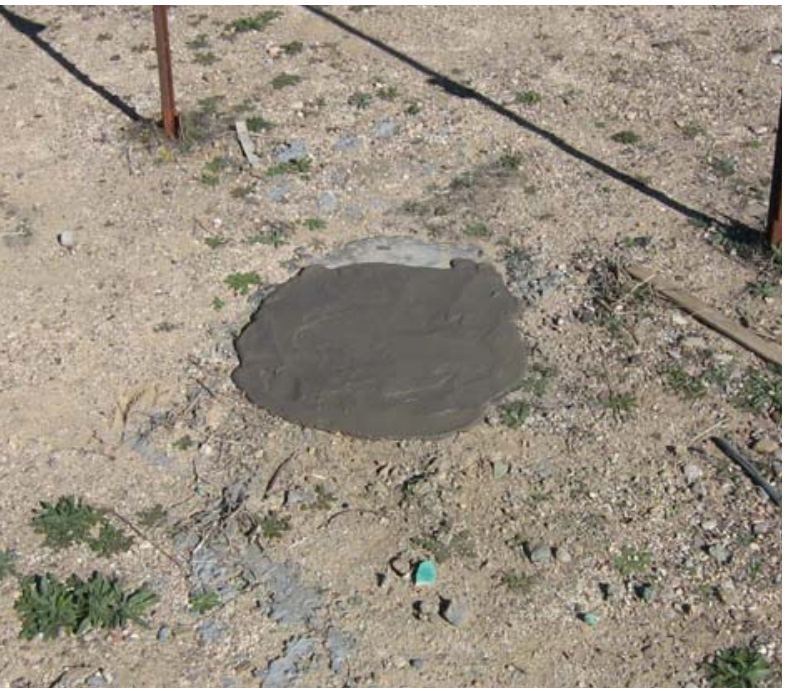

After (11/01/2007) 
FIGURE 10. CAS 03-20-08, INJECTION WELL

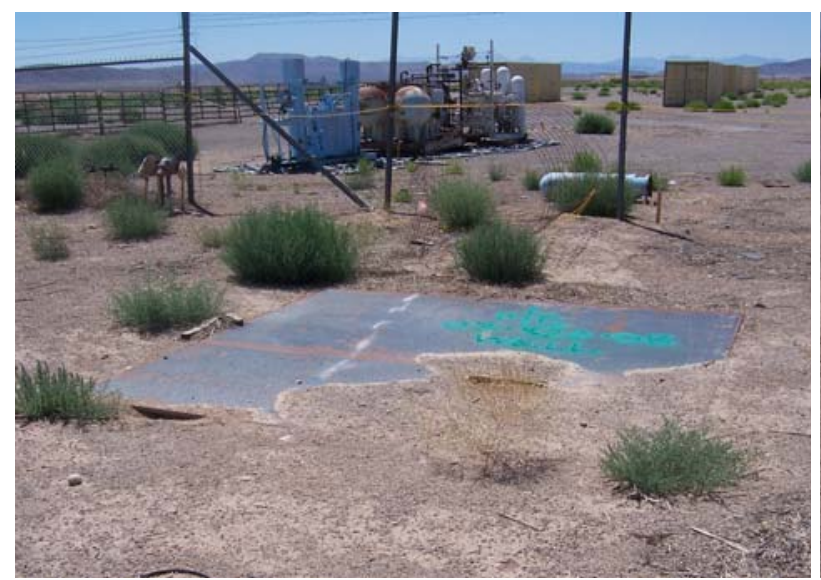

Before (08/09/2007)

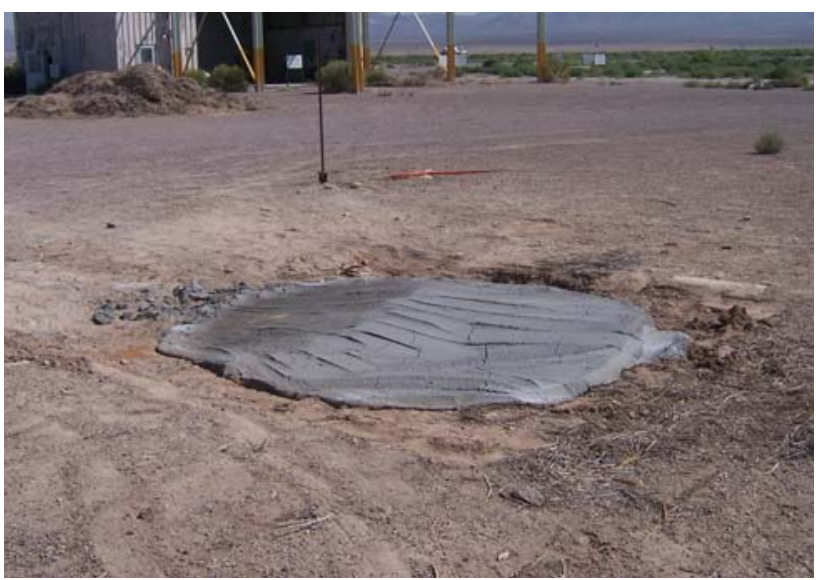

After (09/06/2007)

FIGURE 11. CAS 03-20-08, SUMP

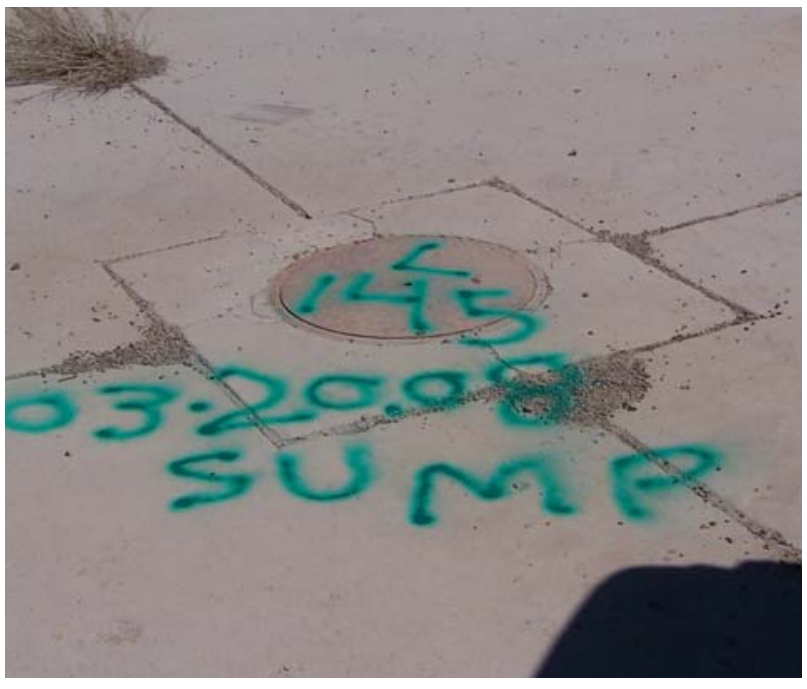

Before (08/09/2007)

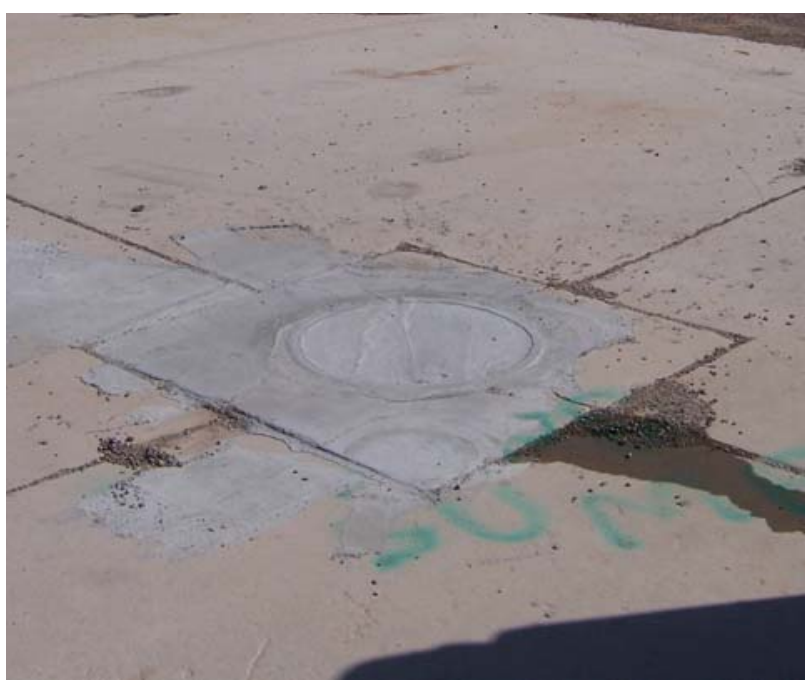

After (09/06/2007) 
was welded to the pipes. The pipe covers were removed, surveyed to verify that radiological contamination was less than the free-release limit established in the NV/YMP Radiological Control Manual (NNSA/NSO, 2004), and placed into metal stockpiles for use elsewhere on the NTS. Photographs of the pipes and sump, before and after closure activities, are provided in Figure 12.

Surface and subsurface soil contamination was closed in place with a UR. Signs were posted on each side of the use-restricted area as a warning about the hazards (Figure 13). A copy of the implemented UR is provided in Appendix A. Post-closure requirements are described in Section 5.2 .

\subsubsection{CAS 03-99-13, Drain and Injection Well}

CAS 03-99-13 is located at the former Core Complex in Area 3 of the NTS. No further action was required for closure of this CAS. As a BMP, the injection well was grouted to grade. The metal cover that had covered the well was surveyed to verify that radiological contamination was less than the free-release limit established in the NV/YMP Radiological Control Manual (NNSA/NSO, 2004), after which it was placed back into metal stockpiles for use elsewhere on the NTS. Photographs of the site before and after closure activities are provided in Figure 14.

\subsection{DEVIATIONS FROM THE CAP AS APPROVED}

Closure activities that deviated from the approved CAP are presented below.

- CAS 03-20-04 (Injection Wells): Approximately 15 gallons of liquid were expected to be present in the steam plant sump; however, there was no liquid in the sump during closure activities. Removal of liquid was therefore not needed.

- CAS 03-20-08 (Injection Well): Approximately 8,310 gallons of liquid were expected to be present in the injection well and the sump; however, there was no liquid in either location during closure activities. Removal of liquid was therefore not needed.

- CAS 03-25-01 (Oil Spills): Approximately 100 gallons of liquid were expected to be present in the north pipe; however, there was little liquid present at the time of closure activities. The minimal liquid was stabilized in place using a drier grout mixture, after which the remainder of the pipe was filled with grout.

- All CASs: Steel lids from the wells, sumps, and holes were taken to the one of the shops on the NTS for reuse rather than disposing of them in the sanitary landfill.

\subsection{Corrective Action Schedule as Completed}

Closure activities for CAU 145 started in August 2007 and were completed in September 2007. Details of the schedule are provided in Table 2. 
Figure 12. CAS 03-25-01, VerTiCAL PIPES AND SUMP

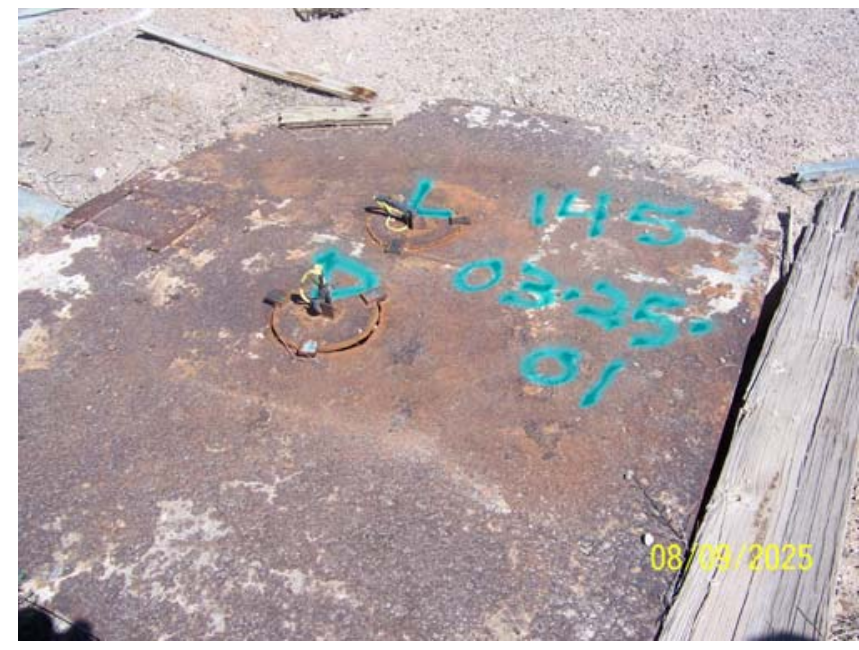

Before (08/09/2007)

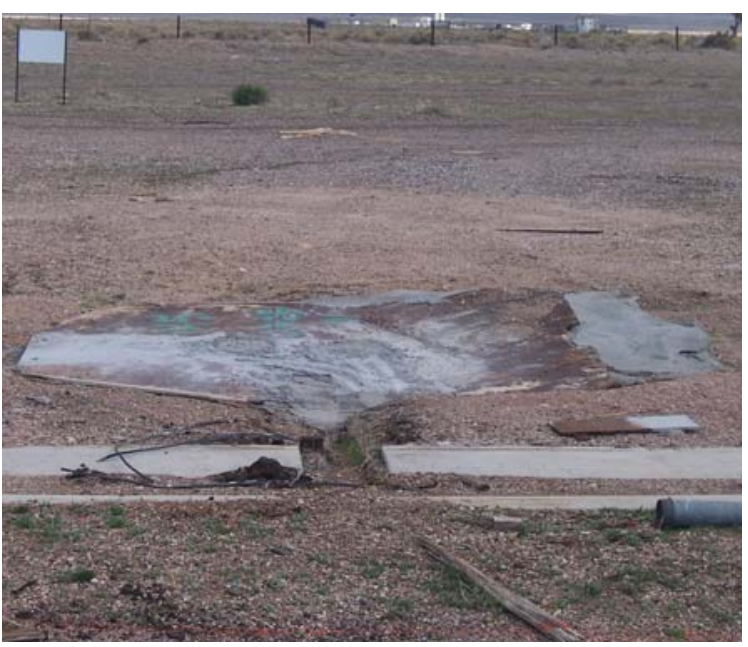

After (10/16/2007)

FigURE 13. CAS 03-25-01, Use RESTRICTION SIGN

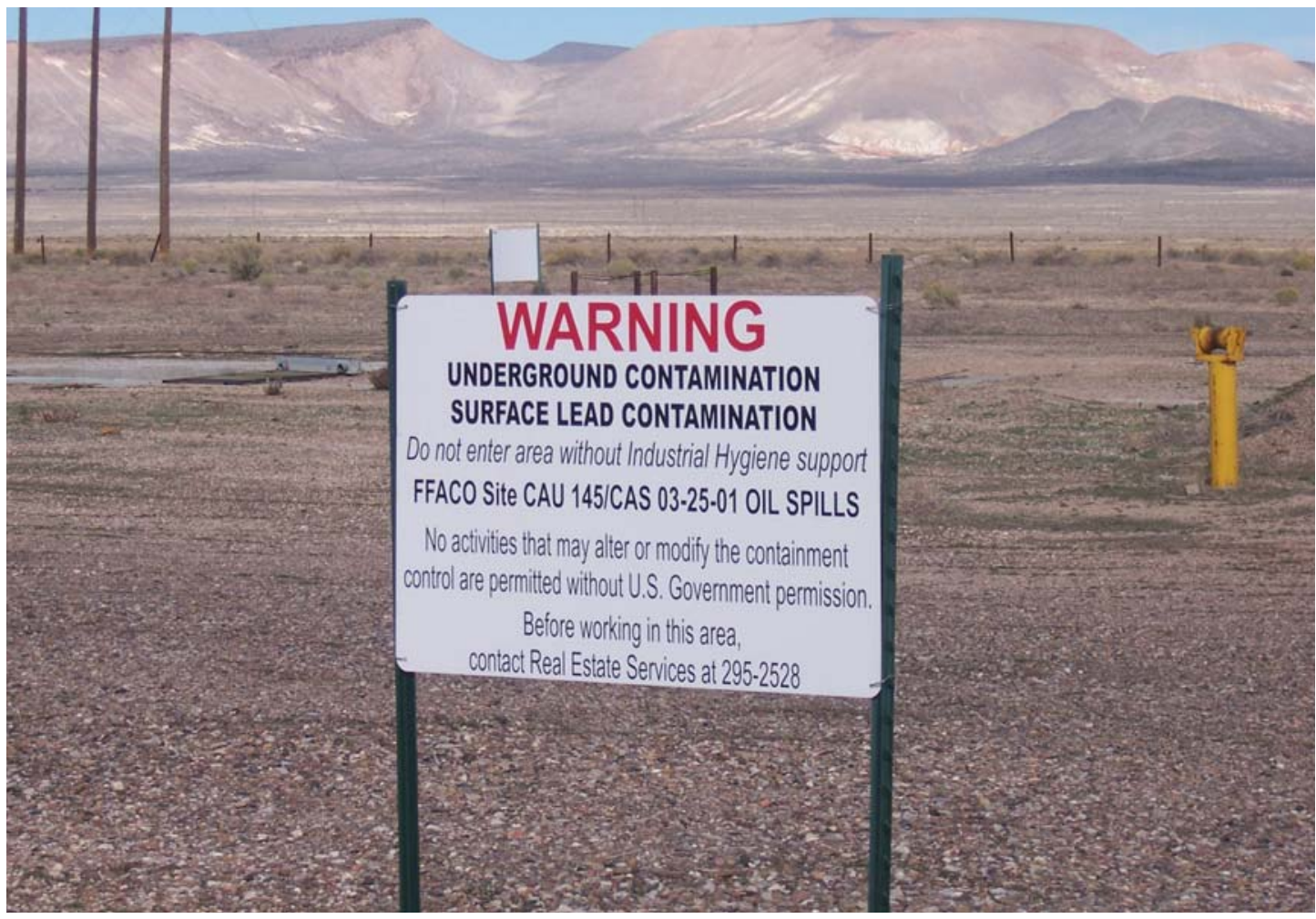

$(10 / 15 / 2007)$ 
FIGURE 14. CAS 03-99-13, INJECTION WELL

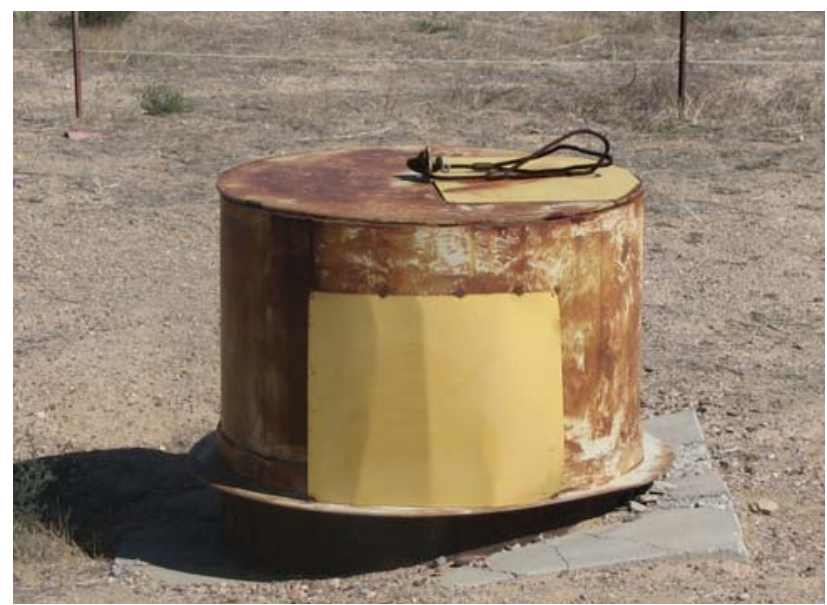

Before (09/07/2007)

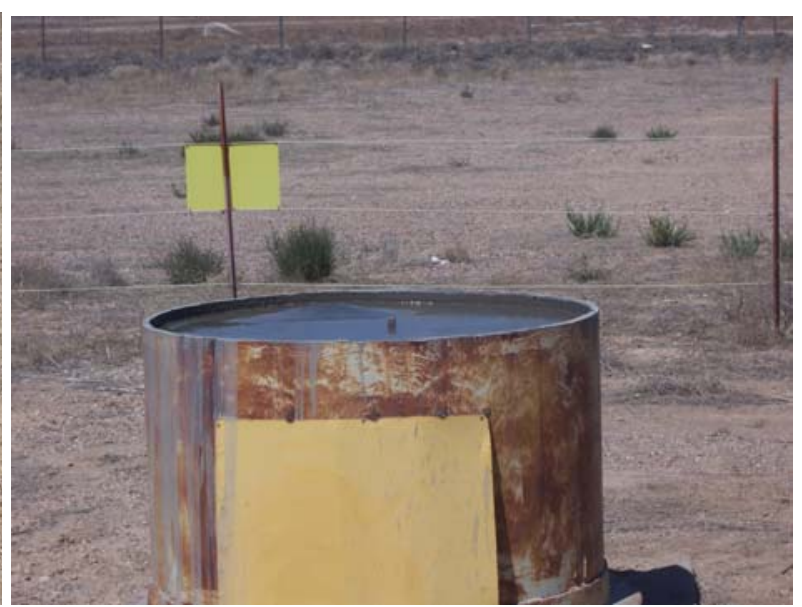

After (09/17/2007)

Table 2. CAU 145 Closure Activities Schedule

\begin{tabular}{||l|c|c||}
\hline \multicolumn{1}{|c|}{ CORRECTIVE ACTION SITE } & START DATE & END DATE \\
\hline \hline 03-20-01, Core Storage Holes & August 28, 2007 & August 28, 2007 \\
\hline 03-20-02, Decon Pad and Sump & September 4, 2007 & September 4, 2007 \\
\hline 03-20-04, Injection Wells & August 28, 2007 & September 13, 2007 \\
\hline 03-20-08, Injection Well & August 29, 2007 & September 4, 2007 \\
\hline 03-25-01, Oil Spills & September 12, 2007 & September 26, 2007 \\
\hline 03-99-13, Drain and Injection Well & September 17, 2007 & September 17, 2007 \\
\hline
\end{tabular}




\subsection{Site Plan/Survey Plat}

As-built drawings were not required for CAU 145 closure activities. Figures showing the locations of the surveyed points delineating the use-restricted areas are provided in Appendix A of this report. URs were implemented for the following CASs:

- CAS 03-20-02 (Decon Pad and Sump) was use-restricted to maintain the site at an Occasional Use Area designation and thereby prevent overexposure of personnel to contaminants that exceed permissible action levels. An administrative UR was implemented. No signs were posted.

- CAS 03-20-04 (Injection Wells) was use-restricted to maintain the site at an Occasional Use Area designation and thereby prevent overexposure of personnel to contaminants that exceed permissible action levels. An administrative UR was implemented. No signs were posted.

- CAS 03-20-08 (Injection Well) was use-restricted to maintain the site at an Occasional Use Area designation and thereby prevent overexposure of personnel to contaminants that exceed permissible action levels. An administrative UR was implemented. No signs were posted.

- CAS 03-25-01 (Oil Spills) was use-restricted for surface lead contamination and subsurface pentachlorophenol and arsenic contamination. UR signs were posted on all four sides of the use-restricted area.

Information regarding the URs is provided in Section 4.2, and post-closure requirements are identified in Section 5.2. 


\subsection{WASTE DISPOSITION}

All waste was managed according to applicable federal and state regulations, U.S. Department of Energy orders, and NTS Management and Operations Contractor procedures. Waste had been adequately characterized during the corrective action investigation such that additional waste characterization sample collection was not necessary. The only waste stream generated during closure activities at CAU 145 consisted of liquid waste. Approximately 700 gallons of liquid were placed into the Area 12 Sewage Lagoon where it will be treated with other septage, rather than solidifying and added to waste disposal units. There is no disposition paperwork for liquid added to the Area 12 Sewage Lagoon.

Waste minimization practices were applied where possible. Metal covers from the holes, sumps, and wells were screened to verify that radiological contamination was less than the free-release limit established in the NV/YMP Radiological Control Manual (NNSA/NSO, 2004). The covers were then placed into metal stockpiles for use elsewhere on the NTS. 
Closure Report - CAU 145

Section: Waste Disposition

Revision: 0

Date: February 2008

THIS PAGE INTENTIONALLY LEFT BLANK 


\subsection{CLOSURE VERIFICATION RESULTS}

Site closure was verified by visually observing and taking photographs to document that closure activities had been completed. The corrective action investigation showed that no further action was required at five of the sites, and the remaining CAS was closed in place. No samples were needed to verify closure at these sites. Details regarding chemical and radiological concentrations remaining at each CAS are found in the CAU 145 CADD (NNSA/NSO, 2006a).

\subsection{Data Quality Assessment}

There are no data to assess for CAU 145 closure activities because the collection of additional data was not needed.

\subsection{USE RESTRICTION}

URs have been implemented for the following CASs:

- CAS 03-20-02, Decon Pad and Sump

- CAS 03-20-04, Injection Wells

- CAS 03-20-08, Injection Well

- CAS 03-25-01, Oil Spills

\subsubsection{CAS 03-20-02, Decon Pad and Sump}

An administrative UR has been implemented for this CAS to maintain the current and future land use at the Occasional Use Area scenario. The Occasional Use Area scenario assumes that individuals will not visit the area for more than 50 workdays in their lifetime. Because this is an administrative UR, site inspections and monitoring are not required and signs have not been posted. The CAU Use Restriction Information form and figure, showing the locations of the surveyed points delineating the use-restricted area, are provided in Appendix A.

\subsubsection{CAS 03-20-04, Injection Wells}

An administrative UR has been implemented for this CAS to maintain the current and future land use at the Occasional Use Area scenario. The Occasional Use Area scenario assumes that individuals will not visit the area for more than 50 workdays in their lifetime. Because this is an administrative UR, site inspections and monitoring are not required and signs have not been posted. The CAU Use Restriction Information form and figure, showing the locations of the surveyed points delineating the use-restricted area, are provided in Appendix A.

\subsubsection{CAS 03-20-08, Injection Well}

An administrative UR has been implemented for this CAS to maintain the current and future land use at the Occasional Use Area scenario. The Occasional Use Area scenario assumes that individuals will not visit the area for more than 50 workdays in their lifetime. Because this is an administrative UR, site inspections and monitoring are not required and signs have not been 
posted. The CAU Use Restriction Information form and figure, showing the locations of the surveyed points delineating the use-restricted area, are provided in Appendix A.

\subsubsection{CAS 03-25-01, Oil Spills}

This CAS has been use restricted for lead contamination of surface soil and for pentachlorophenol and arsenic contamination of subsurface soil. UR signs are posted on all four sides of the use-restricted area to warn against intrusive activity according to the FFACO UR posting guidance (FFACO, 2003). The signs also include a cautionary statement about the surface hazard.

Annual site inspections will be required to ensure that the UR has been maintained and the signs are intact and legible. The CAU Use Restriction Information form and figure, showing the locations of the surveyed points delineating the use-restricted area, are provided in Appendix A. Details on the post-closure requirements are included in Section 5.2. 


\subsection{CONCLUSIONS AND RECOMMENDATIONS}

\subsection{CONCLUSiONS}

The following site closure activities were performed at CAU 145 and are documented in this CR.

- CAS 03-20-01 (Core Storage Holes) was closed by taking no further action with implementation of BMPs. As a BMP, the seven core storage holes were filled with grout to grade.

- CAS 03-20-02 (Decon Pad and Sump) was closed by taking no further action with implementation of BMPs. The following were undertaken as BMPs: (1) the sump was filled with grout to grade, and (2) an administrative UR was established to warn against working at this location for more than 50 cumulative workdays because of exposure hazards.

- CAS 03-20-04 (Injection Wells) was closed by taking no further action with implementation of BMPs. The following were undertaken as BMPs: (1) liquid was removed from an injection well (Site C) and a steel-cased hole (Site E) to the extent practical; (2) three injection wells (Sites A, B, and C), two sumps (Site D and the steam plant sump), and one steel-cased hole (Site E) were filled with grout to grade; and (3) an administrative UR was established to warn from working at this location for more than 50 cumulative workdays because of exposure hazards.

- CAS 03-20-08 (Injection Well) was closed by taking no further action with implementation of BMPs. The following were undertaken as BMPs: (1) the injection well and sump were opened and found to be dry, (2) both the sump and the injection well were filled with grout to grade, and (3) an administrative UR was established to warn from working at this location for more than 50 cumulative workdays because of exposure hazards.

- CAS 03-25-01 (Oil Spills) was closed in place with administrative controls. The following closure activities were undertaken: (1) the north pipe was opened and the liquid level was found to be minimal; (2) the north and south pipes, and the sump surrounding them, were grouted to grade; (3) UR signs were posted; and (4) a UR was implemented for an area that is contaminated with surface lead and subsurface pentachlorophenol and arsenic.

- CAS 03-99-13 (Drain and Injection Well) was closed by taking no further action with implementation of BMPs. As a BMP, the injection well was filled with grout to grade.

\subsection{Post-Closure Requirements}

The only CAS with post-closure requirements is CAS 03-25-01 (Oil Spills). Post-closure requirements consist of annual inspections and documentation of the inspections and any repairs in the annual NTS post-closure letter report.

\subsubsection{Inspections}

Inspections will be performed annually to verify that signs are in place and legible and the UR is maintained. Maintenance or repair needs that are identified will be scheduled within 90 working days of discovery and documented in writing at the time the work is done. Inspection results will 
be documented in the combined NTS post-closure annual letter report. The report will include a discussion of observations and will describe any maintenance activities performed since the last inspection was performed.

\subsubsection{Monitoring}

No monitoring other than visual inspections will be required for CAU 145.

\subsection{RECOMMENDATIONS}

Since closure activities for CAU 145 have been completed following the Nevada Division of Environmental Protection (NDEP)-approved CAP (NNSA/NSO, 2006b), NNSA/NSO requests the following:

1. Provision of a Notice of Completion from NDEP to NNSA/NSO for the closure of CAU 145

2. Transfer of CAU 145 from Appendix III to Appendix IV, Closed CAUs, of the FFACO (FFACO, 1996) 


\subsection{REFERENCES}

Federal Facility Agreement and Consent Order, 1996 (as amended January 2007). Agreed to by the state of Nevada; the U.S. Department of Energy, Environmental Management; the U.S. Department of Defense; and the U.S. Department of Energy, Legacy Management.

FFACO Use Restriction Posting Guidance for NNSA/NSO and Associated Contractors, 2003. Las Vegas, NV.

FFACO, see Federal Facility Agreement and Consent Order.

NNSA/NSO, see U.S. Department of Energy, National Nuclear Security Administration Nevada Site Office.

U.S. Department of Energy, National Nuclear Security Administration Nevada Site Office, 2004. NV/YMP Radiological Control Manual. DOE/NV/11718--079-Rev 5. Las Vegas, NV.

U.S. Department of Energy, National Nuclear Security Administration Nevada Site Office, 2006a. Corrective Action Decision Document for Corrective Action Unit 145: Wells and Storage Holes, Nevada Test Site, Nevada. DOE/NV--1118. Las Vegas, NV.

U.S. Department of Energy, National Nuclear Security Administration Nevada Site Office, 2006b. Corrective Action Plan for Corrective Action Unit 145: Wells and Storage Holes, Nevada Test Site, Nevada. DOE/NV--1173. Las Vegas, NV. 
Closure Report - CAU 145

Section: References

Revision: 0

Date: February 2008

THIS PAGE INTENTIONALLY LEFT BLANK 
Revision: 0

Date: February 2008

APPENDIX A

\section{USE RESTRICTION DOCUMENTATION}




\section{CAU Use Restriction Information}

CAU Number/Description: CAU 145: Wells and Storage Holes

Applicable CAS Numbers/Descriptions: CAS 03-20-02: Decon Pad and Sump

Contact (organization/project): NNSA/NSO Federal Sub-Project Director

Surveyed Area (UTM, Zone 11, NAD 27, meters):

\begin{tabular}{|c|c|c|}
\hline UR PoINTS & NoRTHING & EASTING \\
\hline Northwest Corner & $4,102.496 .7$ & $584,347.46$ \\
\hline Northeast Corner & $4,102.496 .7$ & 584.415 .64 \\
\hline Southeast Corner & $4,102.460 .06$ & 584.415 .64 \\
\hline Southeast Corner 2 & 4.102 .460 .06 & $584,392.8$ \\
\hline Southeast Corner 3 & 4.102 .393 .46 & $584,392.8$ \\
\hline Southwest Corner & $4,102.393 .46$ & 584.347 .46 \\
\hline
\end{tabular}

Survey Date: $\underline{05 / 22 / 2006}$ Survey Method (GPS, etc): $\underline{\text { GPS }}$

Site Monitoring Requirements: None

Required Frequency (quarterly, annually?): Nol applicable

If Monitoring Has Started, Indicate last Completion Date: Nol applicable

\section{Use Restrictions}

The future use of any land related to this Corrective Action Unit (CAU), as described by the above surveyed location, is restricted from any DOE or Air Force activity that may alter or modify the containment control as approved by the state and identified in the CAU Closure Report or other CAU documentation unless appropriate concurrence is obtained in advance.

Comments: This use restriction restricts individuals from working on this site for more than 50 workdays to avoid overexposure to site contaminants. See the Closure Report and the Corrective Action Decision Document for additional information on the condition of the site(s) and the contaminants.

Submitted By: _ /

Date: $2-6-6 d^{2}$

cc with copy of survey map (paper and digital (dgn) formats):

CAU Files (2 copies) 


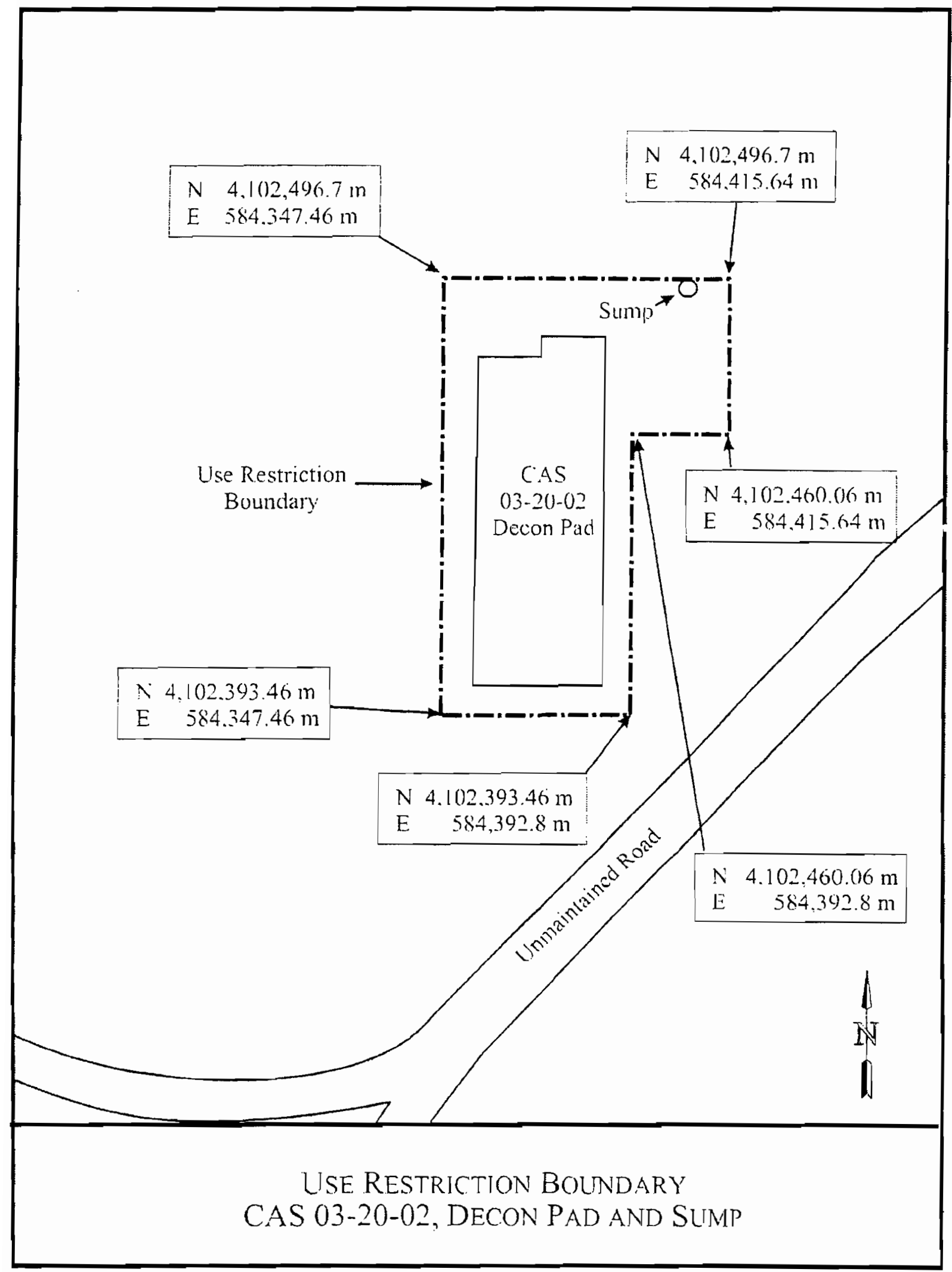




\section{CAU Use Restriction Information}

CAU Number/Description: CAU 145: Wells and Storage Holes

Applicable CAS Numbers/Descriptions: CAS 03-20-04: Injection Wells

Contact (organization/project): NNSA/NSO Federal Sub-Project Director

Surveyed Area (UTM, Zone 11, NAD 27, meters):

\begin{tabular}{|c|c|c|}
\hline UR PoINTS & NoRTHING & EASTING \\
\hline Northwest Corner & $4,100,563.01$ & $584,436.72$ \\
\hline Northeast Corner & $4,100,563.01$ & $584,466.94$ \\
\hline Southeast Corner & $4,100,531.22$ & $584,466.94$ \\
\hline Southwest Corner & $4,100,531.22$ & 584.436 .72 \\
\hline
\end{tabular}

Survey Date: $\underline{05 / 22 / 2006}$ Survey Method (GPS, etc): $\underline{\text { GPS }}$

Site Monitoring Requirements: None

Required Frequency (quarterly, annually?): Not applicable

If Monitoring Has Started, Indicate last Completion Date: Not applicable

\section{Use Restrictions}

The future use of any land related to this Corrective Action Unit (CAU), as described by the above surveyed location, is restricted from any DOE or Air Force activity that may alter or modify the containment control as approved by the state and identified in the CAU Closure Report or other CAU documentation unless appropriate concurrence is obtained in advance.

Comments: This use restriction restricts individuals from working on this site for more than 50 workdavs to avoid overexposure to site contaminants. See the Closure Report and the Corrective Action Decision Document for additional information on the condition of the site(s) and the contaminants.

Submitted By: /s/ Kevin Cabble Date: 2 _

cc with copy of survey map (paper and digital (dgn) formats):

CAU Files ( 2 copies) 


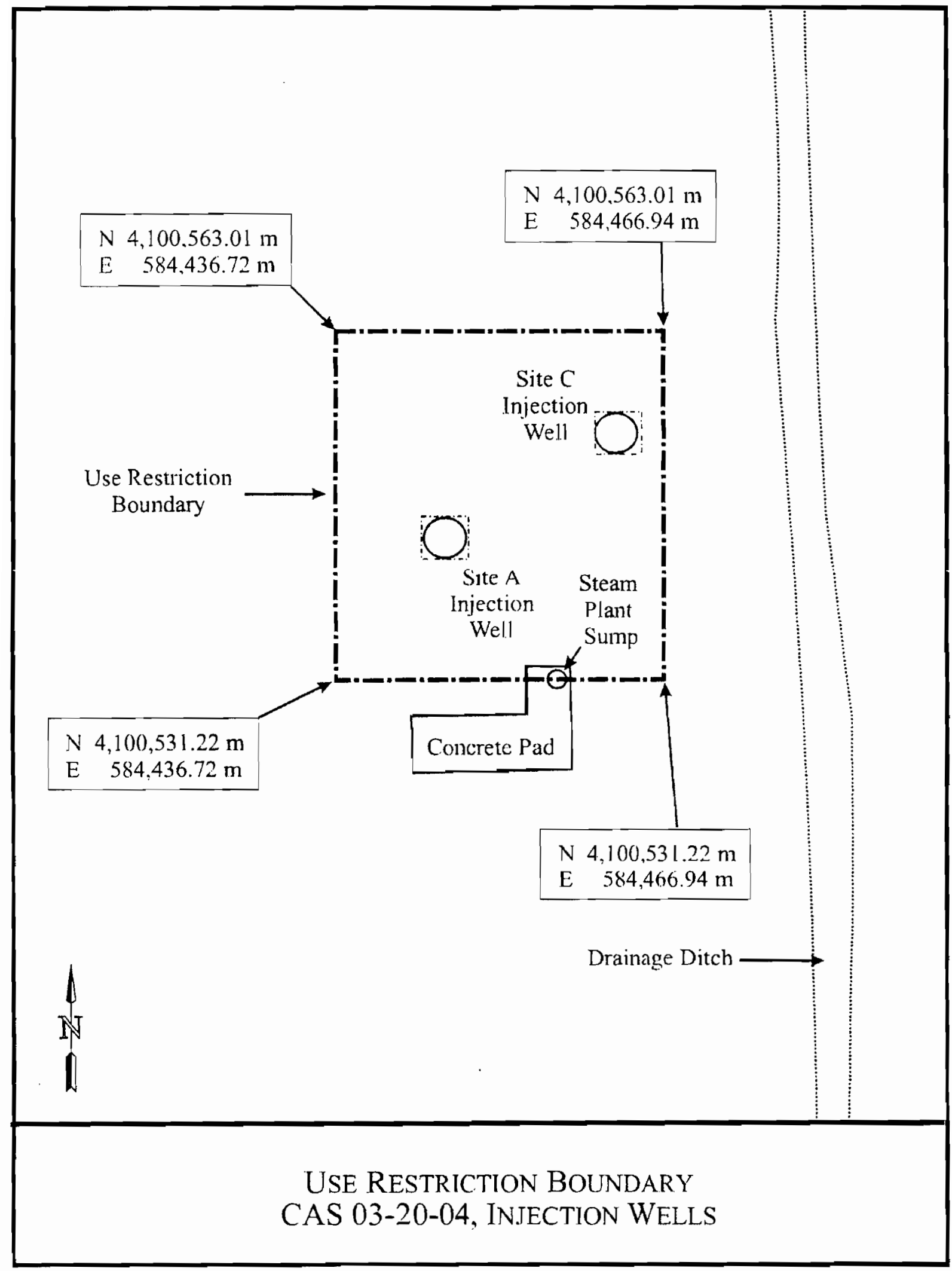




\section{CAU Use Restriction Information}

CAU Number/Description: CAU 145: Wells and Storage Holes

Applicable CAS Numbers/Descriptions: CAS 03-20-08: Injection Well

Contact (organization/project): NNSA/NSO Federal Sub-Project Director

Surveyed Area (UTM, Zone 11, NAD 27, meters):

\begin{tabular}{|c|c|c|}
\hline$:$ UR PoiNTS & NoRTHING & EASTING \\
\hline Northwest Corner & $4,099,061.21$ & $585,682.57$ \\
\hline Northeast Corner & $4,099,061.21$ & $585,700.28$ \\
\hline Southeast Corner & $4,099,008.19$ & $585,700.28$ \\
\hline Southwest Corner & $4,099,008.19$ & $585,682.57$ \\
\hline
\end{tabular}

Survey Date: $\underline{05 / 22 / 2006}$ Survey Method (GPS, etc): $\underline{\text { GPS }}$

Site Monitoring Requirements: None

Required Frequency (quarterly, annually?): Not applicable

If Monitoring Has Started, Indicate last Completion Date: Not applicable

\section{Use Restrictions}

The future use of any land related to this Corrective Action Unit (CAU), as described by the above surveyed location, is restricted from any DOE or Air Force activity that may alter or modify the containment control as approved by the state and identified in the CAU Closure Report or other CAU documentation unless appropriate concurrence is obtained in advance.

Comments: This use restriction restricts individuals from working on this site for more than 50 workdays to avoid overexposure to site contaminants. See the Closure Report and the Corrective Action Decision Document for additional information on the condition of the site(s) and the contaminants.

Submitted By: $\quad / s /$ Kevin Cabble Date: $2 .-6-08$

cc with copy of survey map (paper and digital (dgn) formats): CAU Files ( 2 copies) 


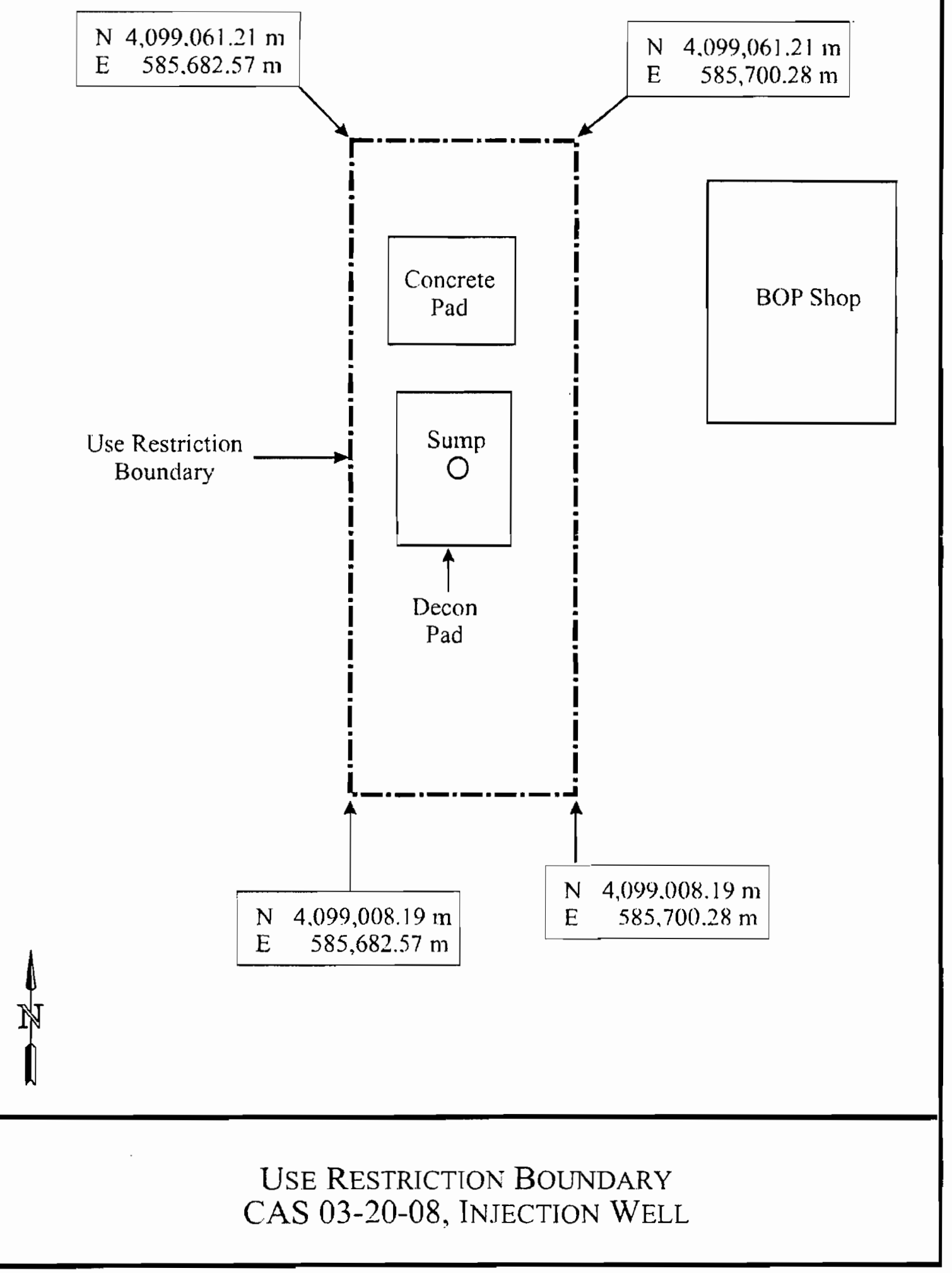




\section{CAU Use Restriction Information}

CAU Number/Description: CAU 145: Wells and Storage Holes

Applicable CAS Numbers/Descriptions: CAS 03-25-01: Oil Spills

Contact (organization/project): NNSA/NSO Federal Sub-Proiect Director

Surveyed Area (UTM, Zone 11, NAD 27, meters):

\begin{tabular}{|c|c|c|}
\hline UR POINTS & NORTHING & EASTING \\
\hline Northwest Corner & $4,100.674 .65$ & $584,333.255$ \\
\hline Northeast Corner & $4,100,674.65$ & 584.398 .800 \\
\hline Southeast Corner & $4,100,631.665$ & $584,401.183$ \\
\hline Southwest Corner & $4,100,633.283$ & $584,334.146$ \\
\hline
\end{tabular}

Survey Date: 10/30/2007 Survey Method (GPS, etc): $\underline{\text { GPS }}$

Site Monitoring Requirements: Visual inspection of postings and UR maintenance

Required Frequency (quarterly, annually?): Annually

If Monitoring Has Started, Indicate last Completion Date: Not applicable

\section{Use Restrictions}

The future use of any land related to this Corrective Action Unit (CAU), as described by the above surveyed location, is restricted from any DOE or Air Force activity that may alter or modify the containment control as approved by the state and identified in the CAU Closure Report or other CAU documentation unless appropriate concurrence is obtained in advance.

Comments: This use restriction restricts individuals from working on this site for more than 50 workdays to avoid overexposure to site contaminants. Also, lead is present on the ground surface at concentrations as high as 6,500 milligrams per kilogram $(\mathrm{mg} / \mathrm{kg})$. See the Closure Report and the Corrective Action Decision Document for additional information on the condition of the site(s) and the contaminants.

Submitted By: /s/ Kevin Cabble Date: $2-6-08$

cc with copy of survey map (paper and digital (dgn) formats):

CAU Files (2 copies) 


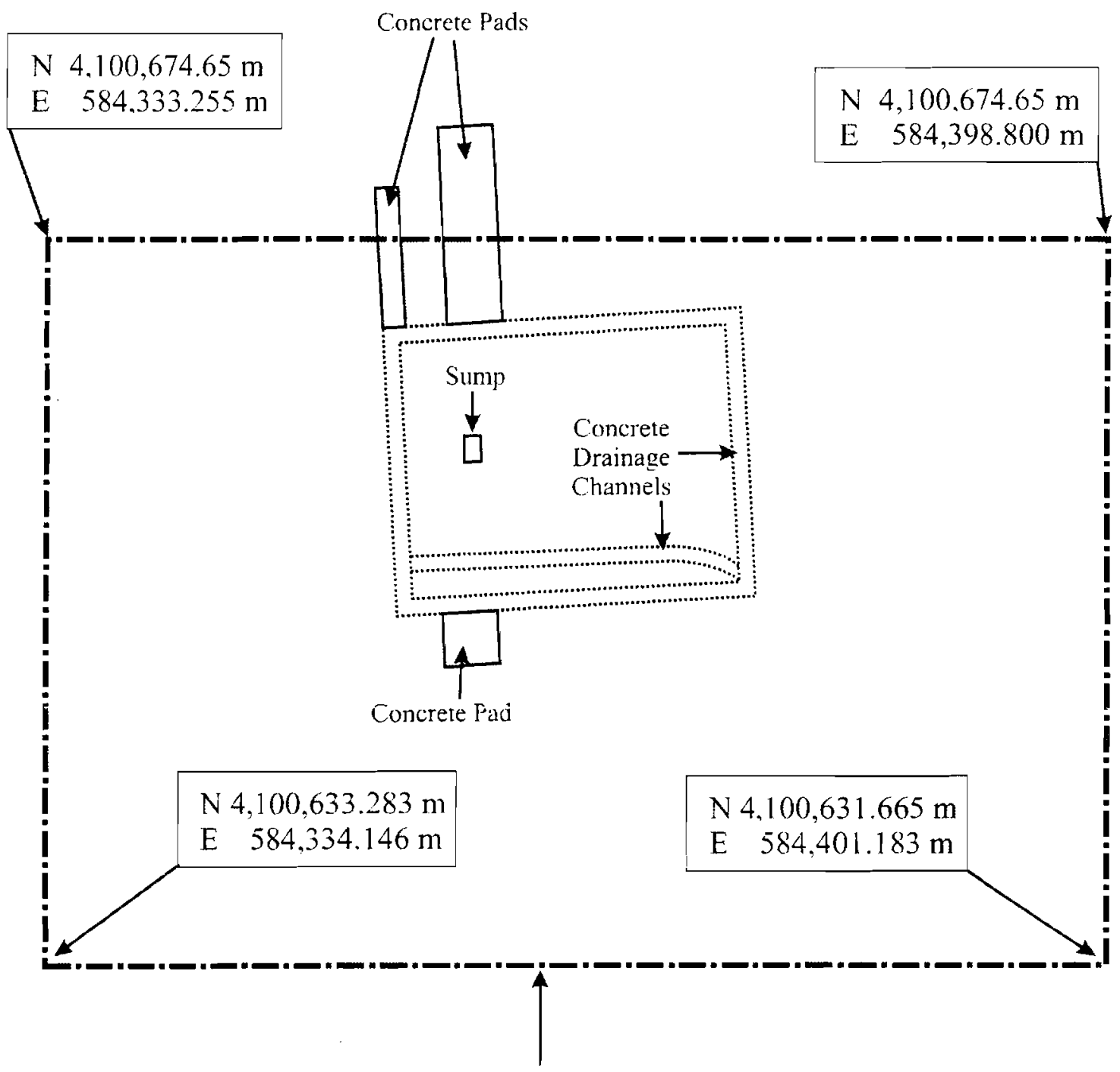

Use Restriction

Boundary
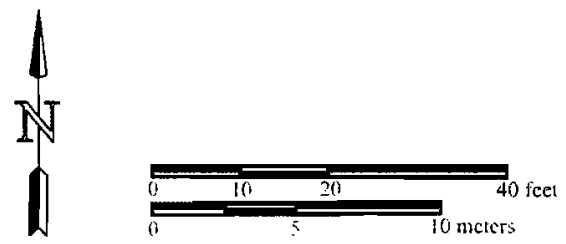

USE RESTRICTION BOUNDARY CAS 03-25-01, OIL SPILLS 
Closure Report - CAU 145

Section: Appendix A

Revision: 0

Date: February 2008

THIS PAGE INTENTIONALLY LEFT BLANK 
Closure Report - CAU 145

Section: Library Distribution

Revision: 0

Date: February 2008

\section{LIBRARY DISTRIBUTION LIST}


Closure Report - CAU 145

Section: Library Distribution

Revision: 0

Date: February 2008

THIS PAGE INTENTIONALLY LEFT BLANK 


\section{LIBRARY DISTRIBUTION LIST}

U.S. Department of Energy

National Nuclear Security Administration

Nevada Site Office

Technical Library

P.O. Box 98518, M/S 505

Las Vegas, NV 89193-8518

U.S. Department of Energy

Office of Scientific and Technical Information

P.O. Box 62

Oak Ridge, TN 37831-0062

Southern Nevada Public Reading Facility

c/o Nuclear Testing Archive

P.O. Box 98521, M/S 400

Las Vegas, NV 89193-8521

Manager, Northern Nevada FFACO

Public Reading Facility

c/o Nevada State Library \& Archives

Carson City, NV 89701-4285
1 (Uncontrolled, electronic copy)

1 (Uncontrolled, electronic copy)

2 (Uncontrolled, electronic copies)

1 (Uncontrolled, electronic copy) 
Closure Report - CAU 145

Section: Library Distribution List

Revision: 0

Date: February 2008

THIS PAGE INTENTIONALLY LEFT BLANK 